\title{
Geochemical Characteristics of Early Permian Pyroclastic Rocks in the Jimunai Basin, West Junggar, Xinjiang (NW China): Implications for Provenance and Tectonic Setting
}

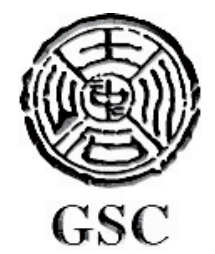

\author{
SHANGGUAN Yunfei ${ }^{1}$, ZHUANG Xinguo ${ }^{1,}$, ,I Baoqing ${ }^{1}$, LI Jing ${ }^{1}$, QUEROL Xavier ${ }^{2}$ and LIU Shunbin ${ }^{3}$ \\ ${ }^{1}$ Key Laboratory of Tectonics and Petroleum Resources of Ministry of Education, China University of Geosciences, Wuhan \\ 430074, China \\ ${ }^{2}$ Institute of Environmental Assessment and Water Research, IDEA-CSIC C/Jordi Girona, 18-26, Barcelona 08034, Spain \\ ${ }^{3}$ Xinjiang Bureau of Prospecting and Development of Geology and Mineral Resources, Urumqi 830000, China
}

\begin{abstract}
During the Late Paleozoic, West Junggar (Xinjiang, NW China) experienced a shift in tectonic setting from compression to extension. Ha'erjiao is an important area for investigating collisional structures, post-collisional structures, and magmatic activities. Based on the petrological and geochemical characteristics of pyroclastic and other volcanic rocks in the Permian Kalagang Formation from the borehole ZKH1205 in the Jimunai Basin, the main types of source rock for the pyroclastic rocks deposited in the basin are identified and their implications for the Early Permian tectonic setting examined. The abundance of basalt and andesite lithic fragments in the pyroclastic rocks, together with the REE characteristics and the contents of transition and high field strength elements show that the source rocks were chiefly intermediate-basic volcanic rocks. High ICV values, low CIA values, low $\mathrm{Rb} / \mathrm{Sr}$ ratios, low $\mathrm{Th} / \mathrm{U}$ ratios and the mineralogical features suggest weak chemical weathering of the source rocks; the geochemical patterns of the pyroclastic rocks might not only have been impacted by crustal contamination but also might be related to the nature of the magma from the source area. The geochemical properties of the pyroclastic rocks distinguish them from arc-related ones, and such samples plot in the within-plate basalt (WPB) field in some diagrams. This is consistent with the formation background of the Early Permian volcanic rocks in this region.
\end{abstract}

Key words: pyroclastic rock, provenance, tectonic setting, Kungurian, Central Asian Orogenic Belt

Citation: Shangguan et al., 2021. Geochemical Characteristics of Early Permian Pyroclastic Rocks in the Jimunai Basin, West Junggar, Xinjiang (NW China): Implications for Provenance and Tectonic Setting. Acta Geologica Sinica (English Edition), 95(3): 794-809. DOI: 10.1111/1755-6724.14412

\section{Introduction}

Northern Xinjiang, an important part of the Central Asian Orogenic Belt (CAOB), is composed of the most complex accretionary collages on the planet and is responsible for considerable Phanerozoic juvenile crustal growth (e.g., Xiao et al., 2015, 2017; Windley et al., 2007; Wilde, 2015; Huang et al., 2018). This region is situated between the European, Siberian, and Tarim cratons and the Sino-Korean craton (Jahn et al., 2000, 2004; Windley et al., 2007; Safonova et al., 2009, 2011; Xiao et al., 2008, 2010, 2013; Kröner et al., 2013, 2014) and consists mainly of former oceanic islands, seamounts, oceanic plateaus, island arcs, accretionary complexes, ophiolites, and microcontinents resulting from a prolonged subductionaccretion process and multi-stage arc-arc or arc-continent collisions (Khain et al., 2002; Buckman and Aitchison, 2004; Kovalenko et al., 2004; Windley et al., 2007; Xiao et al., 2010; Wilhem et al., 2012; Windley et al., 2007; Kröner et al., 2014; Safonova, 2017), including the Tianshan, Junggar, and Chinese Altay. Thus, this is an ideal region to investigate post-collisional structures and magmatic activities of the CAOB because of the well-

\footnotetext{
* Corresponding author. E-mail: xgzhuang@cug.edu.cn
}

exposed ophiolitic belts (Irtysh, Kelameili, and North Tianshan ophiolitic belt in the Late Paleozoic), and volcanic rocks, sedimentary rocks, and juvenile granitoids (Wang and Xu 2006; Xiao et al., 2008; Brookfield, 2000; Windley et al., 2002, 2007; Kang et al., 2019).

Post-collisional geodynamic processes during a significant period of the tectonic evolution in the Late Paleozoic in the Junggar (e.g., Chen and Jahn, 2004; Han et al., 2006; Su et al., 2006; Zhang et al., 2015), and Western Mediterranean, Alpine-Himalayan and Appalachian orogens (e.g., Duggen et al., 2005; Whalen et al., 2006; Conticelli et al., 2009) have been widely discussed, and which were defined by Liegeois (1998) (Fig. 1). Wang and Xu et al. (2006) proposed that the postcollisional period ranged from the Early Carboniferous (Viséan) to the Late Permian. Zhou et al. (2008) investigated that the geochemical characteristics of different types of granite bodies (I-type and A2-type) differ from each other in the two formative stages of the Saur area (337 \pm 4-302.6 Ma; 297.9-290.7 Ma), which indicate a post-collision tectonic environment and reflect the change in tectonic conditions from compression to extension. In addition, the presence of bimodal volcanic rocks, A-type granites and molasse deposits in the Early 


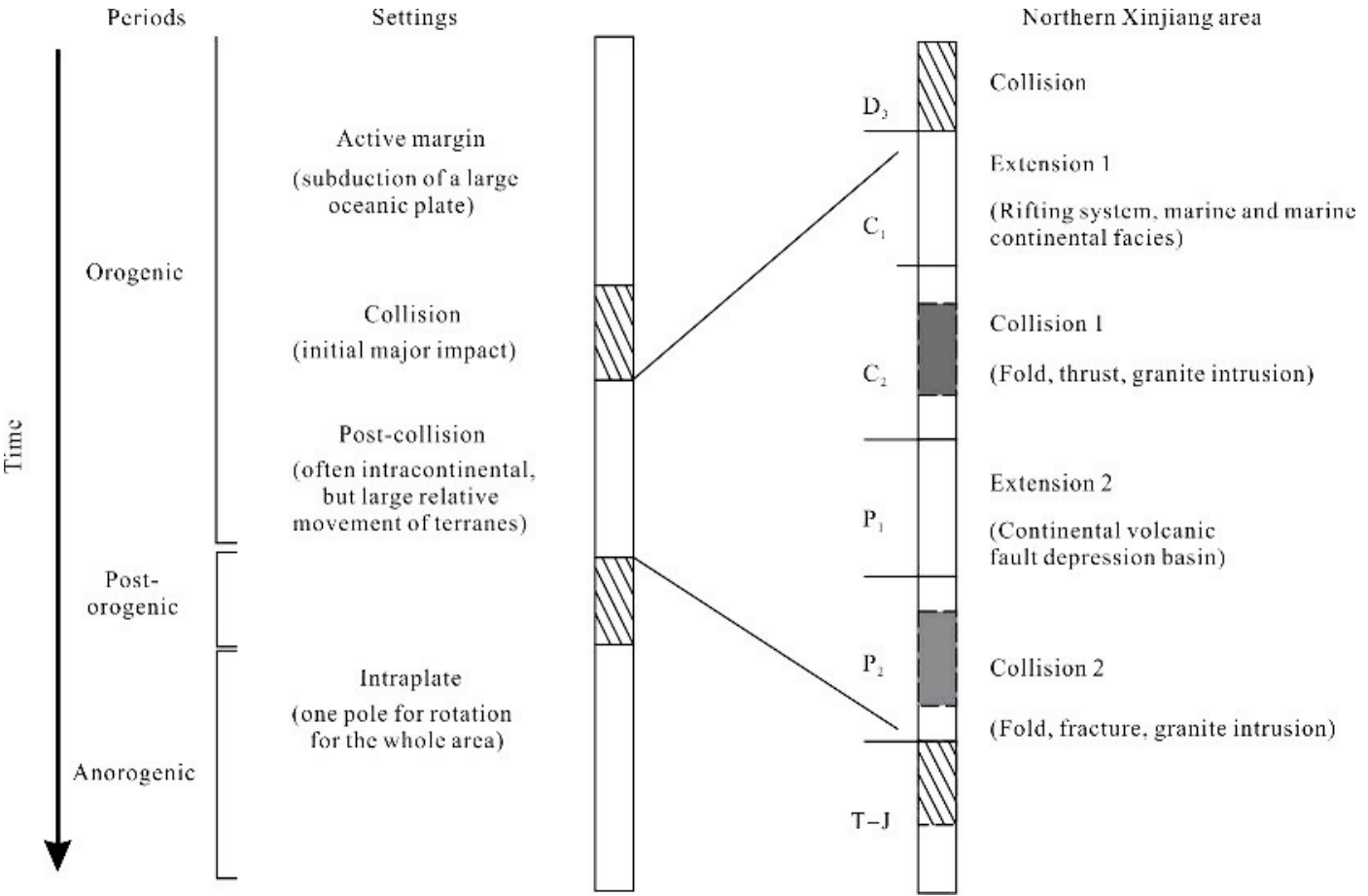

Fig. 1. Diagram showing the evolution of orogeny in northern Xinjiang (After Liegeoi, 1998, and Wang et al., 2006).

Permian also indicate that West Junggar had entered a post -collisional evolutionary stage during the latest Carboniferous-Middle Permian (Han et al., 2006; Su et al., 2006; Zhou et al., 2006, 2008; Chen et al., 2010). Previous studies mainly focused on volcanic rocks (e.g. Cai et al., 2012), including ophiolites (e.g. Safonova et al., 2012), and intrusive rocks (e.g. Zhou et al., 2008; Chen et al., 2010) in this region, where geochronology and geochemical characteristics were used to elucidate the Carboniferous structural style and evolutionary process. To date, few studies have been conducted on Paleozoic strata within the basin (e.g. Zheng et al., 2007; Li et al., 2015), especially the Permian strata, hindering a complete understanding of the tectonic framework of the West Junggar.

In this paper, we report the new whole-rock geochemistry data of the Early Permian pyroclastic rocks from borehole ZKH1205 in the Jimunai Basin. Our aim is to provide new evidence for the tectonic evolution of the northern West Junggar region.

\section{Geological Setting}

The Jimunai Basin, located in the northern West Junggar basin, is distributed along the Irtysh-Zaysan suture zone (Fig. 2), which marks the terminal stage of the entire evolution of the Irtysh-Zaysan Ocean and the collision between the Siberian and Kazakhstan-Junggar continents or, alternatively, the amalgamation between the Altai and Zharma-Saur terranes (Dobretsov, 2003; Sennikov et al., 2003; Buslov et al., 2001, 2004; Xiao et al., 2009; Li et al., 2015). Faults are widely developed in this region, which mainly include thrusting faults and strike-slip shear faults with an approximately E-W orientation. The main regional fold structures include the Saur synclinorium and the Halabayi anticlinorium, and the main body of the study area is located on the southern wing of the Saur synclinorium, near its axis (Zhou et al., 2006). Regional faults control the structural framework and stratigraphic distribution of the Saur synclinorium. Volcanic activity in the region occurred during the midDevonian to early Permian, which resulted in extensive development of granite intrusions. There are six main felsic and alkali granite intrusions, including I-type granites (the Tasite, Sentasi, Wokensala, and Kaerjia plutons) that were emplaced between $337 \pm 4$ Ma and 302.6 $\mathrm{Ma}$, and A-type (A2) granites (the Kuoyitasi and Qiaqihai plutons) that were emplaced between 297.9 and 290.7 Ma (Zhou et al., 2008) (Fig. 2c).

The Carboniferous sedimentary infill of the ZaysanJimunai Basin can be divided into two stages, which resulted from accretionary processes and were a response to Carboniferous arc-related tectonic evolution ( $\mathrm{Li}$ et al., 2016). The Lower and Middle Carboniferous sediments that filled the basin are dominated by shallow marine sediments, and then volcanic material entered the basin as the volcanic arc grew northward. With the closure of the Irtysh-Zaysan Ocean in the Late Carboniferous, the sediments of the Early Carboniferous pre-arc basin were buried and uplifted during the collision and combination of the Saur and Altai island arcs (Li, 2016). The sea gradually retreated westward to the Zaysan basin, with the eastern part first transitioning to a terrestrial depositional environment ( $\mathrm{Li}$ et al., 2016). The ocean closed in the Late Carboniferous, and the whole area was in a tectonic environment of post-collision extension, entering the intracontinental evolutionary stage (Li et al., 2015). Therefore, the period from the Late carboniferous to the 


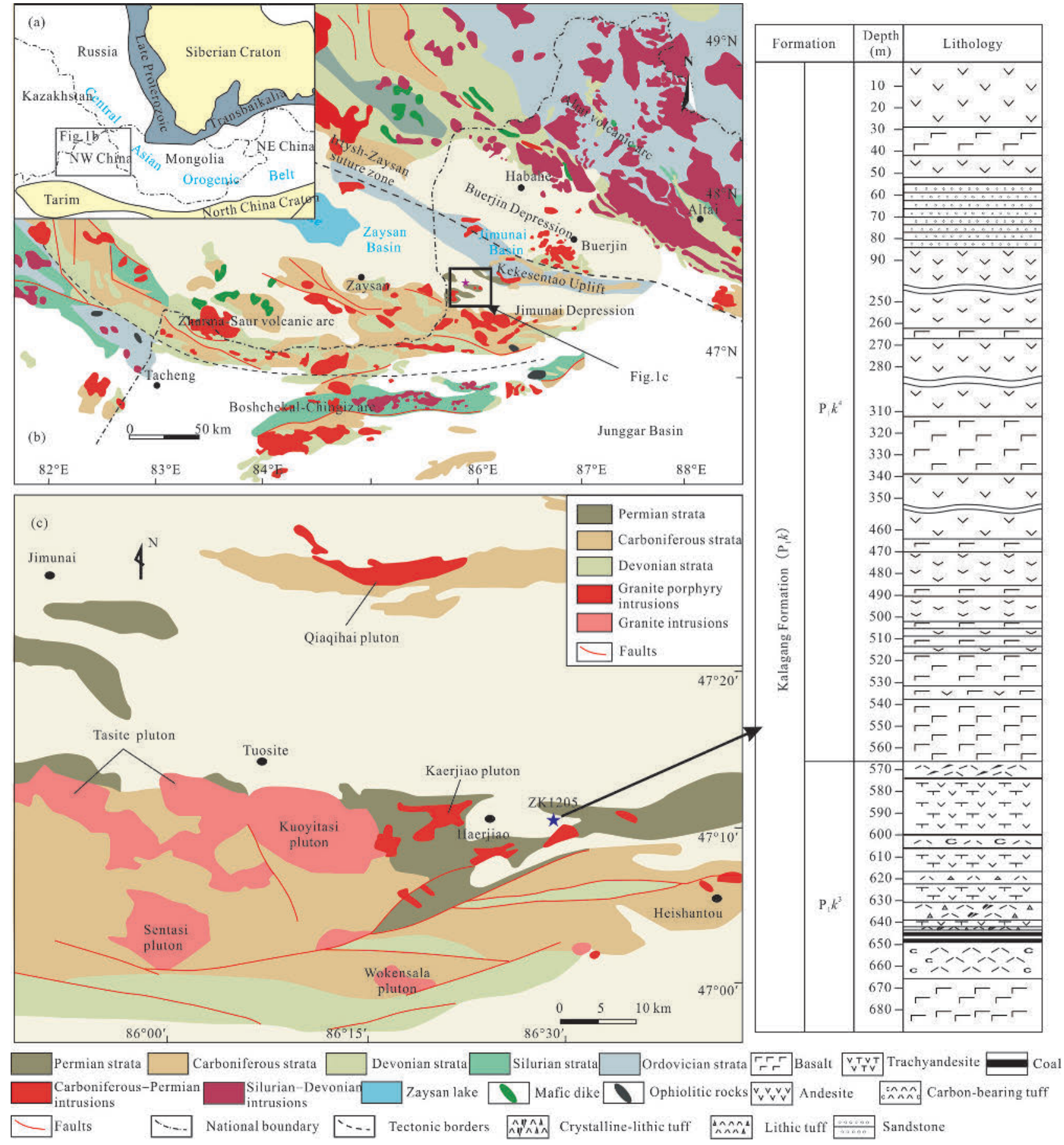

Fig. 2. (a) Simplified tectonic map of the Central Asian Orogenic Belt (Jahn et al., 2004; Windley et al., 2007) with the approximate location of Fig. 1b. (b) Geological map of eastern Kazakhstan to southern Altai area showing the location of the Zaysan-Jimunai Basin (Jimunai Depression). (c) Geologic sketch map in Saur region in west Junggar, Xinjiang (Zhou et al., 2008).

Early Permian is considered to be an important transition in terms of the tectonic background from subduction to collisional accretion in this region (Buslov et al., 2004; Windley et al., 2007; Vladimirov et al., 2008; Yang et al., 2014).

The study area includes outcrops of Devonian, Carboniferous, Permian, and Quaternary strata. The Devonian strata comprise the Hongguleleng, Zhulumute,
Yundukala, and Saurshan groups, which are mainly composed of pyroclastic rocks and mudstones. The Lower Carboniferous strata (Nalinkala, Halabayi and Heishantou groups) are composed mainly of shallow-coastal terrigenous clastic rocks, pyroclastic rocks and intermediate-acidic volcanic rocks and the Upper Carboniferous Qiaqihai and Jimunai groups are mainly marine terrigenous clastic rocks with a small amount of 
intermediate-acidic volcanic rocks. The Permian strata include the Haerjiawu and Kalagang formations, which consist of intermediate-acidic volcanic rocks, pyroclastic rocks, and normal coal-bearing clastic rocks. the former are mainly distributed near Jimunai, and the latter exposed near Ha'erjiao. The Quaternary strata are composed of unconsolidated sand and gravel beds.

The Kalagang Formation (Fm.) is the main coal-bearing stratum, formed in the Early Permian, as determined by previous studies. Zhou et al. (2006) suggested that the Kalagang Fm. volcanic rocks were formed in the Early Permian by analysing Ar-Ar isotopes giving a date of 282 Ma. Li et al. (2015) found a typical Permian sporopollen assemblage including fern spores in several sets of mudstone or tuff in the Kalagang Fm. The preserved plant fossils also provide biostratigraphic evidence for the formation age (Windley et al., 2002). Based on its coalbearing conditions and eruption cycles, the Kalagang Fm. is divided into four lithologic sections: the first is the lower coal-bearing section; the second comprises intermediate-acidic rocks and tuff; the third is the upper coal-bearing section; and the fourth is further intermediate rocks and tuff/s (Li et al., 2019). The borehole ZKH1205 is located in the eastern part of Ha'erjiao and passes through the Neogene and into the Lower Permian Kalagang Fm. strata (Fig. 2c). The third lithologic section here is composed of gray tuffaceous sandstone, light grayblack, black tuffaceous rocks, carbonaceous tuffaceous rocks and gray-white volcanic rocks and the fourth lithologic section consists mainly of dark gray, gray and gray-green andesite, amygdaloidal andesite and graygreen, black-green basalt and amygdaloidal basalt.

\section{Samples and Analytical Methods}

In this study, four volcanic rock samples (H-1-1, H-3-1, $\mathrm{H}-4$, and $\mathrm{H}-5)$ and 10 pyroclastic rock samples were collected from the lower coal-bearing section in the Lower Permian Kalagang Fm. from borehole ZKH1205 (Fig. 3). Fresh unweathered samples were collected for petrological and geochemical analysis. Each sample was crushed and milled in a mortar and passed through a 200-mesh sieve for geochemical analyses.

Petrological characteristics analysis was completed at the Key Laboratory of Tectonics and Petroleum Resources at China University of Geosciences (Wuhan). Major oxides were analyzed by a Primus II X-ray fluorescence spectrometer (XRF) at Wuhan Sample Solution Analytical Technology Co., Ltd. In the analysis, $0.6 \mathrm{~g}$ dry sample together with $6.0 \mathrm{~g}$ of flux $\left(\mathrm{Li}_{2} \mathrm{~B}_{4} \mathrm{O}_{7}: \mathrm{LiBO}_{2}: \mathrm{LiF}=9: 2: 1\right)$ and $0.3 \mathrm{~g}$ oxidant $\left(\mathrm{NH}_{4} \mathrm{NO}_{3}\right)$ were placed in a platinum crucible to fuse in a melting furnace at $1150^{\circ} \mathrm{C}$ for 14 minutes. Loss on ignition (LOI) was calculated on the dried samples heated up to a temperature of $1000^{\circ} \mathrm{C}$.

Trace element analysis of whole-rock samples was also carried out also at Wuhan Sample Solution Analytical Technology Co., Ltd. using an Agilent 7700e inductively coupled plasma mass spectrometer (ICP-MS), and detailed procedures as described by Liu et al., (2008): (1) 200mesh samples were dried in an oven at $105^{\circ} \mathrm{C}$ for 12 hours; (2) $50 \mathrm{mg}$ of powdered sample was accurately

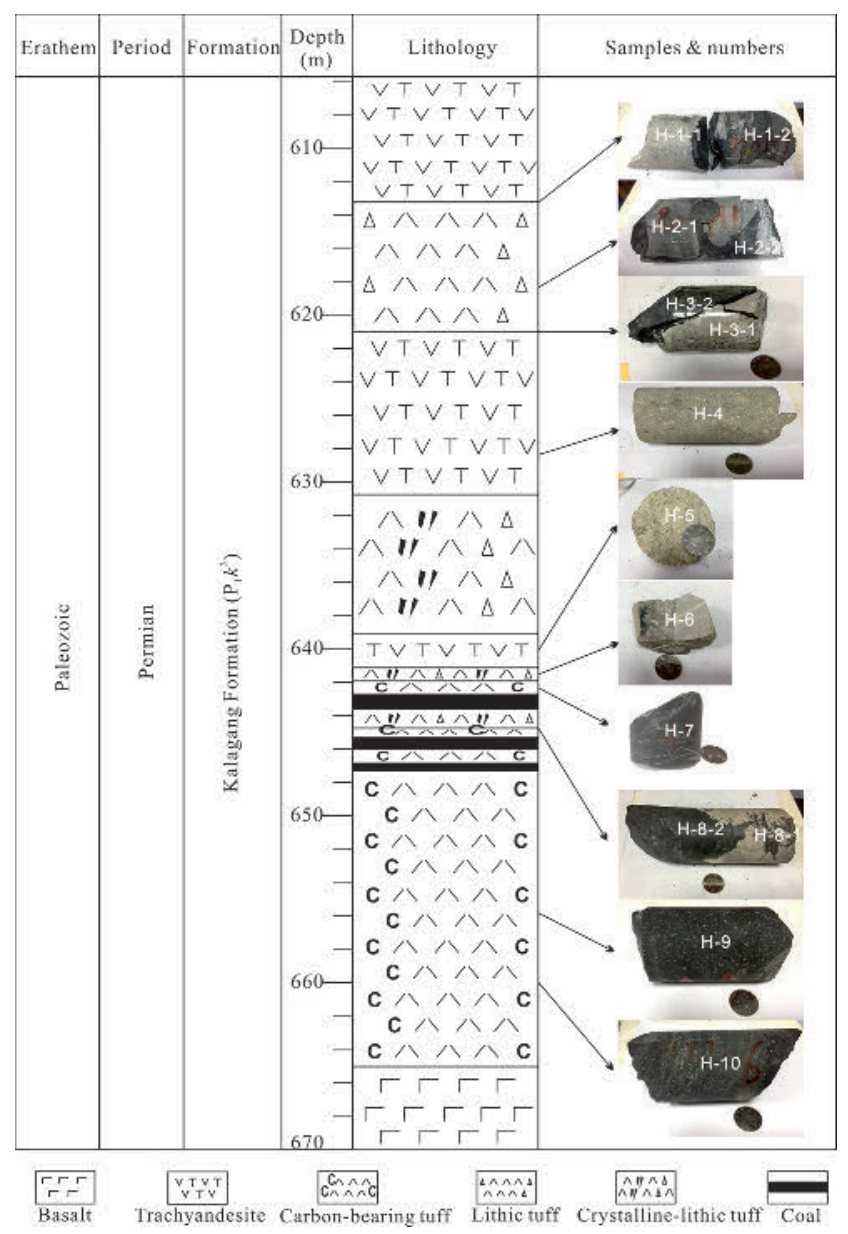

Fig. 3. Comprehensive stratigraphic column of lithology, sampling sites and photographs of Early Permian volcanic rocks and volcaniclastic rocks from borehole ZKH1205.

weighed and placed in a Teflon bomb; (3) $1 \mathrm{ml}$ of highpurity $\mathrm{HNO}_{3}$ and $1 \mathrm{ml}$ of high-purity $\mathrm{HF}$ were slowly added in turn; (4) the Teflon bomb was placed in a steel bushing, then tightened and heated for more than 24 hours in an oven at $190^{\circ} \mathrm{C}$; (5) when the Teflon bomb cooled, the cap was opened, and the bomb was steamed on an electric heating plate at $140^{\circ} \mathrm{C}$, before adding $1 \mathrm{ml} \mathrm{HNO}_{3}$ and drying the bomb again; (6) $1 \mathrm{ml}$ high-purity $\mathrm{HNO}_{3}, 1$ $\mathrm{ml}$ of MQ water and $1 \mathrm{ml}$ of the internal standard element In were added (1 ppm concentration), then the Teflon bomb was placed into the steel bushing again, tightened and heated in the oven at $190^{\circ} \mathrm{C}$ for over 12 hours; (7) the solution was transferred into a polyethylene material bottle and diluted with $2 \% \mathrm{HNO}_{3}$ to $100 \mathrm{~g}$ for ICP-MS testing later.

\section{Results}

\subsection{Petrology}

Gray and whitish gray andesite has a bimodal inequigranular texture composed of matrix and phenocrysts (Fig. 4). The phenocrysts (average 70\%) are dominated by plagioclase, and the matrix with hyalopilitic texture shows poor orientation of microcrystalline plagioclase and glass (Fig. 4). 


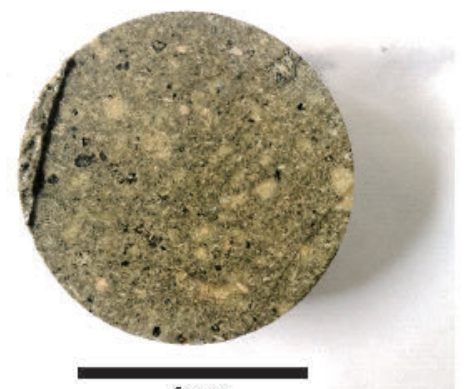

$5 \mathrm{~cm}$

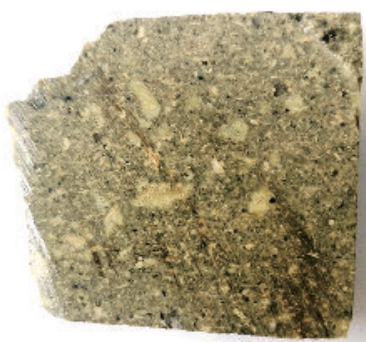

$5 \mathrm{~cm}$
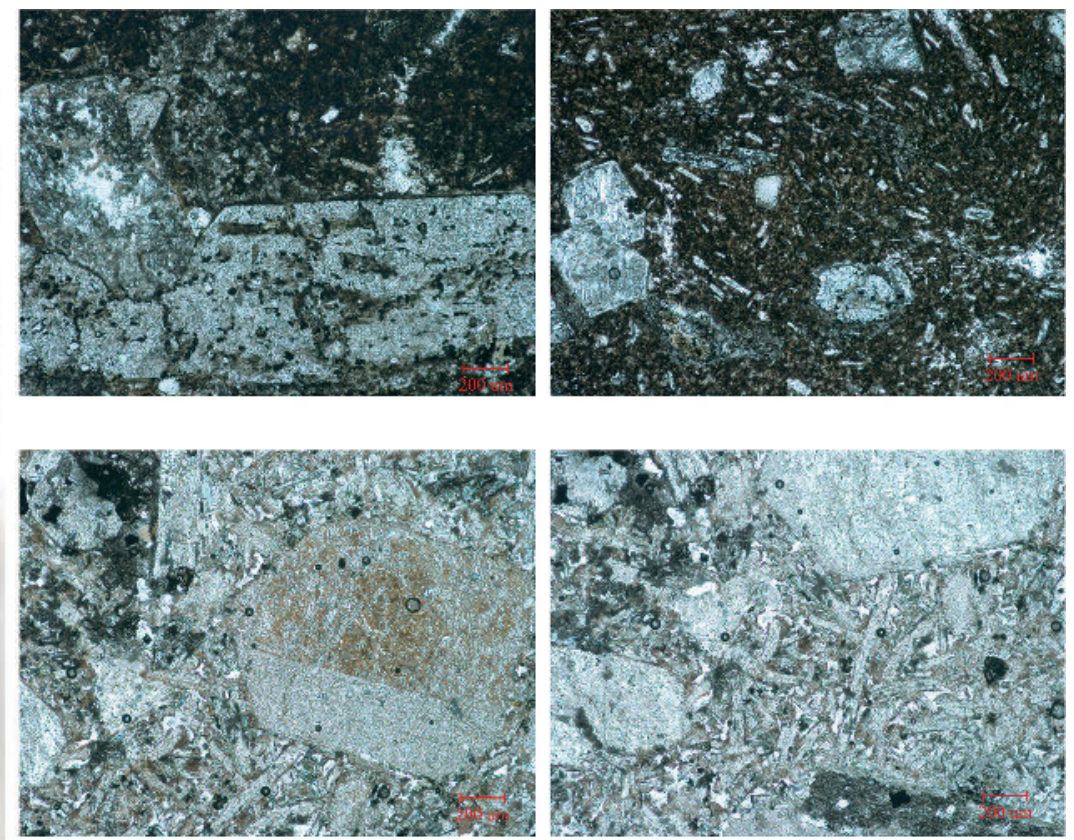

Fig. 4. Photomicrographs of andesites from the Kalagang Formation, cross-polarized light.

(a)

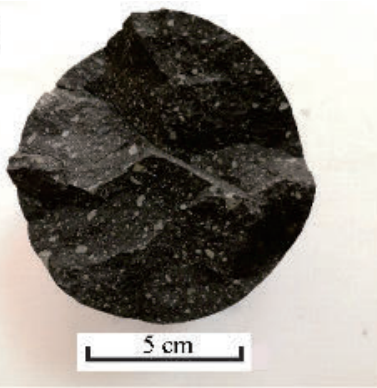

(b)

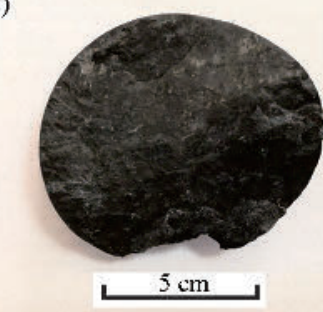

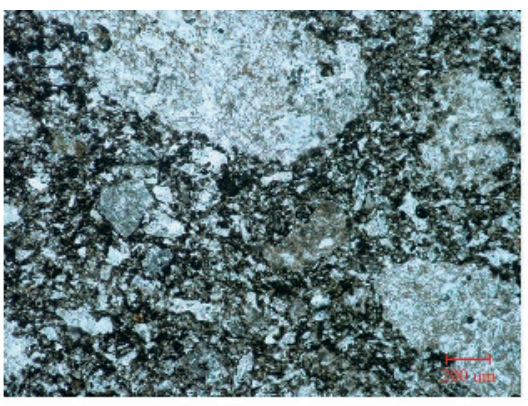

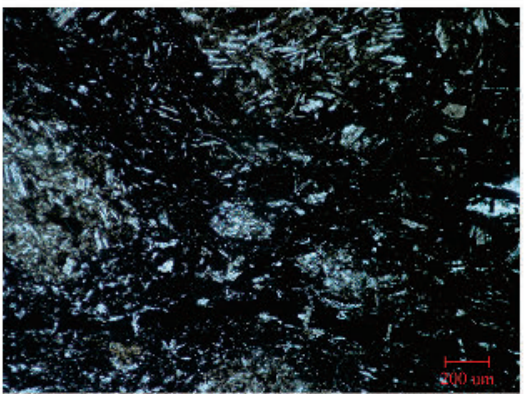

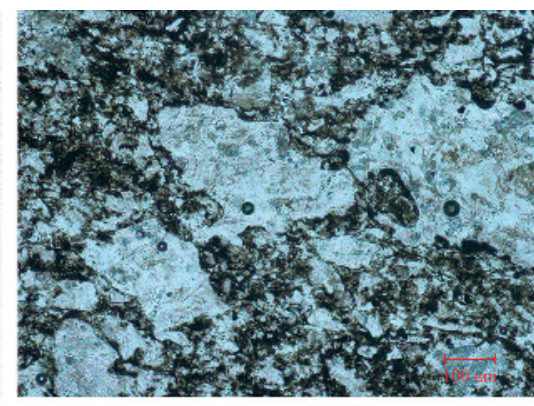

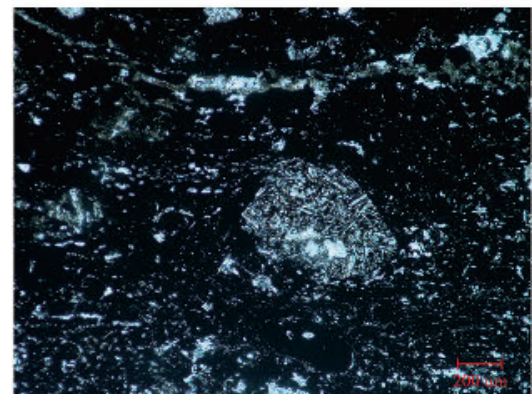

Fig. 5. Photomicrographs of pyroclastic rocks from the Kalagang Formation, cross-polarized light. (a) Lithic tuff rocks; (b) carbon-bearing tuffaceous mudstones.

The pyroclastic rocks have high contents of carbon, as evidenced by hand specimens, and are black and gray. Two different types of pyroclastic rock are identified based on petrological characteristics. The first is a deep gray to black lithic tuff which contains predominantly lithic fragments (87-95\%, average 91\%) and minor contents of feldspar (5-10\%, average $8 \%$ ) and glass (3$6 \%$, average 5\%) (Fig. 5a). The lithic fragments are mainly basalt or andesite rocks, and generally have poor sorting, ranging from $100 \mu \mathrm{m}$ to $1.5 \mathrm{~mm}$ in size, and angular to subangular rounding (Fig. 5a), which indicates a nearby source and short-distance transport. In addition, some volcanic fragments have vesicular structures. The phenocrysts are mainly plagioclases, with euhedral long prismatic and short and wide planar shapes in some samples (Fig. 5a). The second type is classified as carbonbearing tuffaceous mudstones, which are located near the coal seams either as the roof or floor $(\mathrm{H}-7$, and $\mathrm{H}-8-2)$ and which have relatively low proportions of pyroclastic materials (lithic fragments, crystal clasts, or glass) with a range from $30 \%$ to $50 \%$ (Fig. 5b). The lithic fragments are mainly composed of andesite rocks with angular shapes 
and variable sizes from less than $50 \mu \mathrm{m}$ to more than 200 $\mu \mathrm{m}$. In addition, euhedral short prismatic plagioclases occur not only as phenocrysts of the andesite lithic fragments, which have microcrystal plagioclases and a glass matrix but also as individual crystal clasts together with calcite and minor quartz (Fig. 5b).

\subsection{Geochemistry}

\subsubsection{Volcanic rocks}

The major oxide and trace element concentrations of volcanic and pyroclastic rock samples from borehole
ZKH1205 are listed in Table 1. LOI ranges from 5.2\% to $8.6 \%$, with an average of $6.3 \%$, indicating that the volcanic samples experienced varying degrees of alteration. The major oxides are dominated by $\mathrm{SiO}_{2}$, followed by $\mathrm{Al}_{2} \mathrm{O}_{3}$ and $\mathrm{CaO}$. The sample $\mathrm{H}-1-1$ has a relatively low $\mathrm{SiO}_{2}$ content, but relatively high $\mathrm{Fe}_{2} \mathrm{O}_{3}$, $\mathrm{MnO}, \mathrm{CaO}$ contents and a low Rittmann Indexes $(\delta=$ $\left.\left(\mathrm{K}_{2} \mathrm{O}+\mathrm{Na}_{2} \mathrm{O}\right)^{2} /\left(\mathrm{SiO}_{2}-43\right) ; 7.0\right)$, which indicate an alkaline pattern. This is further confirmed by the fact that $\mathrm{H}-1-1$ falls within the alkaline field in the $\mathrm{SiO}_{2}-\left(\mathrm{K}_{2} \mathrm{O}+\right.$ $\mathrm{Na}_{2} \mathrm{O}$ ) diagram (Le Maitre et al., 1989), whereas the other

Table 1 The concentrations of major (wt \%), trace elements ( $\mathrm{ppm})$ and their sample parameters from Ha'erjiao

\begin{tabular}{|c|c|c|c|c|c|c|c|c|c|c|c|c|c|c|}
\hline & H-1-1(*) & H-1-2 & H-2-1 & H-2-2 & H-3-2 & H-3-1(*) & $\mathrm{H}-4(*)$ & $\mathrm{H}-5(*)$ & H-6 & $\mathrm{H}-7$ & H-8-1 & H-8-2 & $\mathrm{H}-9$ & $\mathrm{H}-10$ \\
\hline $\mathrm{SiO}_{2}$ & 51.29 & 34.30 & 39.71 & 57.45 & 32.33 & 63.47 & 61.81 & 65.31 & 44.43 & 48.15 & 35.99 & 21.92 & 51.63 & 33.13 \\
\hline $\mathrm{TiO}_{2}$ & 0.67 & 0.57 & 1.40 & 0.94 & 0.73 & 0.59 & 0.72 & 0.66 & 1.56 & 0.81 & 1.69 & 0.25 & 1.44 & 1.11 \\
\hline $\mathrm{Al}_{2} \mathrm{O}_{3}$ & 15.18 & 11.03 & 17.15 & 15.89 & 14.08 & 13.46 & 15.04 & 14.85 & 15.74 & 12.06 & 16.10 & 6.20 & 17.89 & 13.53 \\
\hline $\mathrm{Fe}_{2} \mathrm{O}_{3}$ & 6.17 & 8.73 & 5.54 & 4.76 & 7.06 & 3.14 & 4.42 & 3.98 & 9.18 & 3.03 & 11.16 & 1.63 & 6.12 & 7.81 \\
\hline $\mathrm{MnO}$ & 0.14 & 0.26 & 0.23 & 0.06 & 0.32 & 0.09 & 0.09 & 0.07 & 0.12 & 0.05 & 0.18 & 0.03 & 0.05 & 0.31 \\
\hline $\mathrm{MgO}$ & 2.21 & 3.21 & 3.73 & 2.51 & 3.94 & 1.30 & 1.91 & 1.20 & 3.59 & 1.49 & 4.83 & 1.63 & 2.95 & 6.62 \\
\hline $\mathrm{CaO}$ & 6.87 & 17.48 & 10.86 & 2.39 & 12.63 & 4.38 & 3.49 & 2.08 & 5.69 & 3.06 & 8.01 & 3.26 & 3.30 & 12.42 \\
\hline $\mathrm{Na}_{2} \mathrm{O}$ & 4.01 & 1.65 & 3.48 & 1.49 & 0.99 & 3.17 & 3.36 & 4.24 & 3.29 & 3.10 & 1.80 & 1.71 & 2.48 & 2.08 \\
\hline $\mathrm{K}_{2} \mathrm{O}$ & 3.61 & 1.33 & 2.93 & 3.00 & 3.85 & 4.14 & 3.22 & 2.29 & 2.29 & 1.55 & 1.12 & 0.68 & 2.42 & 2.01 \\
\hline $\mathrm{P}_{2} \mathrm{O}_{5}$ & 0.24 & 0.34 & 1.03 & 0.12 & 0.15 & 0.23 & 0.29 & 0.24 & 0.34 & 0.39 & 0.36 & 0.02 & 0.32 & 0.63 \\
\hline LOI & 8.55 & 20.72 & 13.96 & 10.73 & 23.11 & 5.48 & 5.82 & 5.20 & 13.37 & 26.63 & 18.42 & 63.04 & 10.51 & 20.01 \\
\hline SUM & 98.93 & 99.62 & 100.02 & 99.34 & 99.18 & 99.45 & 100.16 & 100.09 & 99.60 & 100.32 & 99.66 & 100.36 & 99.10 & 99.64 \\
\hline $\mathrm{Li}$ & 12.3 & 20.4 & 10.9 & 17.6 & 22.2 & 19.2 & 12.8 & 4.52 & 4.54 & 3.32 & 32.7 & 3.39 & 18.5 & 13.8 \\
\hline $\mathrm{Be}$ & 1.26 & 1.49 & 2.66 & 1.93 & 1.94 & 1.02 & 1.70 & 1.24 & 1.70 & 1.04 & 1.80 & 0.41 & 1.41 & 1.38 \\
\hline $\mathrm{Sc}$ & 7.40 & 10.6 & 20.9 & 15.6 & 11.1 & 6.55 & 8.35 & 6.79 & 22.4 & 11.8 & 24.3 & 4.50 & 18.0 & 15.1 \\
\hline $\mathrm{V}$ & 48.1 & 73.2 & 149 & 126 & 95.9 & 42.0 & 64.2 & 45.9 & 194 & 115 & 206 & 33.5 & 191 & 156 \\
\hline $\mathrm{Cr}$ & 42.9 & 51.4 & 131 & 59.5 & 55.9 & 47.7 & 58.6 & 34.1 & 39.9 & 53.6 & 29.2 & 42.8 & 90.3 & 93.4 \\
\hline Co & 8.52 & 13.3 & 33.7 & 14.0 & 23.3 & 9.68 & 9.70 & 6.59 & 32.0 & 16.7 & 37.2 & 3.57 & 30.3 & 24.3 \\
\hline $\mathrm{Ni}$ & 32.7 & 50.6 & 47.3 & 48.8 & 51.6 & 33.5 & 41.6 & 23.6 & 86.4 & 42.8 & 72.7 & 28.0 & 69.7 & 74.7 \\
\hline $\mathrm{Cu}$ & 25.3 & 74.0 & 61.9 & 35.7 & 101 & 57.2 & 19.6 & 9.71 & 63.7 & 36.9 & 69.8 & 9.40 & 67.0 & 57.6 \\
\hline $\mathrm{Zn}$ & 37.6 & 57.3 & 89.8 & 54.9 & 54.6 & 26.8 & 49.0 & 56.7 & 86.3 & 53.2 & 87.4 & 24.9 & 96.8 & 73.2 \\
\hline $\mathrm{Ga}$ & 14.5 & 13.5 & 18.8 & 19.5 & 20.3 & 11.4 & 17.6 & 18.0 & 19.7 & 14.0 & 18.6 & 7.11 & 21.4 & 16.1 \\
\hline $\mathrm{Rb}$ & 46.5 & 18.6 & 55.7 & 60.3 & 48.6 & 52.4 & 57.3 & 44.5 & 36.3 & 29.0 & 19.7 & 19.1 & 41.0 & 30.7 \\
\hline $\mathrm{Sr}$ & 454 & 705 & 523 & 181 & 459 & 345 & 300 & 227 & 703 & 265 & 590 & 293 & 364 & 553 \\
\hline $\mathrm{Y}$ & 21.8 & 18.0 & 45.7 & 25.5 & 16.5 & 18.3 & 17.6 & 18.4 & 28.2 & 20.5 & 30.4 & 8.34 & 22.6 & 19.7 \\
\hline $\mathrm{Zr}$ & 226 & 88.1 & 200 & 239 & 148 & 198 & 205 & 225 & 192 & 164 & 198 & 70.1 & 203 & 115 \\
\hline $\mathrm{Nb}$ & 14.0 & 6.60 & 12.1 & 14.0 & 9.04 & 11.9 & 12.1 & 14.1 & 8.20 & 10.4 & 8.52 & 4.55 & 13.0 & 8.32 \\
\hline Sn & 1.52 & 2.89 & 2.08 & 1.80 & 6.30 & 2.01 & 1.07 & 1.11 & 1.60 & 1.20 & 1.47 & 0.90 & 1.47 & 1.06 \\
\hline Cs & 0.41 & 0.49 & 0.74 & 0.81 & 0.44 & 0.38 & 0.92 & 0.76 & 1.14 & 1.02 & 0.86 & 0.50 & 1.19 & 0.76 \\
\hline $\mathrm{Ba}$ & 1116 & 169 & 195 & 263 & 474 & 1312 & 495 & 109 & 214 & 124 & 150 & 76.3 & 198 & 162 \\
\hline $\mathrm{La}$ & 25.4 & 12.5 & 35.8 & 20.5 & 14.6 & 21.8 & 24.1 & 27.4 & 14.4 & 20.9 & 15.2 & 12.6 & 21.6 & 17.2 \\
\hline $\mathrm{Ce}$ & 51.8 & 26.5 & 103 & 44.8 & 32.0 & 45.5 & 49.1 & 54.7 & 34.8 & 46.2 & 37.4 & 24.8 & 47.9 & 39.9 \\
\hline Pr & 5.94 & 3.41 & 12.9 & 5.21 & 4.01 & 5.17 & 5.54 & 6.15 & 4.63 & 5.62 & 5.04 & 2.86 & 5.90 & 5.13 \\
\hline $\mathrm{Nd}$ & 22.1 & 15.0 & 60.1 & 19.7 & 17.0 & 19.9 & 21.5 & 23.6 & 20.6 & 23.2 & 22.5 & 10.5 & 23.9 & 22.0 \\
\hline $\mathrm{Sm}$ & 4.35 & 3.47 & 14.1 & 3.82 & 4.02 & 4.06 & 4.14 & 4.34 & 5.01 & 4.59 & 5.52 & 1.97 & 4.99 & 4.68 \\
\hline $\mathrm{Eu}$ & 1.09 & 1.49 & 3.58 & 0.91 & 1.26 & 1.06 & 1.18 & 1.14 & 1.56 & 1.12 & 1.64 & 0.44 & 1.29 & 1.60 \\
\hline $\mathrm{Gd}$ & 3.69 & 3.34 & 12.7 & 3.43 & 3.57 & 3.23 & 3.39 & 3.61 & 4.89 & 3.91 & 5.40 & 1.59 & 4.14 & 4.08 \\
\hline $\mathrm{Tb}$ & 0.60 & 0.53 & 1.80 & 0.64 & 0.60 & 0.54 & 0.52 & 0.56 & 0.85 & 0.60 & 0.90 & 0.24 & 0.66 & 0.61 \\
\hline Dy & 3.72 & 3.10 & 9.12 & 4.06 & 3.16 & 3.28 & 3.06 & 3.18 & 4.87 & 3.45 & 5.20 & 1.30 & 3.94 & 3.38 \\
\hline Но & 0.74 & 0.61 & 1.60 & 0.89 & 0.60 & 0.61 & 0.60 & 0.62 & 0.99 & 0.71 & 1.09 & 0.28 & 0.79 & 0.68 \\
\hline $\mathrm{Er}$ & 2.06 & 1.57 & 4.02 & 2.65 & 1.48 & 1.75 & 1.68 & 1.77 & 2.76 & 2.02 & 3.05 & 0.83 & 2.31 & 1.86 \\
\hline $\mathrm{Tm}$ & 0.31 & 0.24 & 0.52 & 0.41 & 0.20 & 0.26 & 0.27 & 0.27 & 0.42 & 0.29 & 0.43 & 0.13 & 0.34 & 0.26 \\
\hline $\mathrm{Yb}$ & 2.01 & 1.46 & 3.35 & 2.75 & 1.31 & 1.64 & 1.65 & 1.75 & 2.56 & 1.95 & 2.68 & 0.88 & 2.07 & 1.62 \\
\hline $\mathrm{Lu}$ & 0.29 & 0.22 & 0.50 & 0.42 & 0.18 & 0.24 & 0.23 & 0.27 & 0.40 & 0.29 & 0.42 & 0.14 & 0.32 & 0.25 \\
\hline $\mathrm{Hf}$ & 5.33 & 2.26 & 4.41 & 5.67 & 3.48 & 4.63 & 4.65 & 5.03 & 4.17 & 3.72 & 4.31 & 1.84 & 4.63 & 2.88 \\
\hline $\mathrm{Ta}$ & 0.89 & 0.36 & 0.60 & 0.90 & 0.52 & 0.79 & 0.80 & 0.91 & 0.49 & 0.59 & 0.54 & 0.33 & 0.72 & 0.45 \\
\hline $\mathrm{Tl}$ & 0.27 & 0.085 & 0.17 & 0.22 & 0.18 & 0.32 & 0.21 & 0.17 & 0.15 & 0.12 & 0.075 & 0.083 & 0.22 & 0.15 \\
\hline $\mathrm{Pb}$ & 7.95 & 2.82 & 15.4 & 5.92 & 3.68 & 7.93 & 6.13 & 9.89 & 2.11 & 5.74 & 3.31 & 2.14 & 10.8 & 5.42 \\
\hline Th & 5.43 & 1.10 & 1.53 & 3.65 & 1.87 & 4.71 & 5.20 & 5.41 & 1.29 & 2.78 & 1.29 & 2.86 & 2.46 & 1.35 \\
\hline $\mathrm{U}$ & 2.93 & 0.41 & 0.81 & 1.03 & 0.55 & 1.84 & 2.03 & 2.02 & 0.46 & 0.94 & 0.46 & 0.89 & 0.85 & 0.41 \\
\hline$\Sigma \mathrm{REE}$ & 145.90 & 91.57 & 309.39 & 135.71 & 100.48 & 127.36 & 134.55 & 147.74 & 127.05 & 135.43 & 136.88 & 67.02 & 142.74 & 123.00 \\
\hline$(\mathrm{La} / \mathrm{Yb})_{\mathrm{CN}}$ & 8.51 & 5.79 & 7.20 & 5.02 & 7.54 & 8.98 & 9.83 & 10.53 & 3.80 & 7.25 & 3.83 & 9.70 & 7.01 & 7.15 \\
\hline$(\mathrm{La} / \mathrm{Sm})_{\mathrm{CN}}$ & 3.67 & 2.28 & 1.60 & 3.37 & 2.29 & 3.38 & 3.66 & 3.97 & 1.82 & 2.87 & 1.73 & 4.02 & 2.72 & 2.31 \\
\hline$(\mathrm{Gd} / \mathrm{Yb})_{\mathrm{CN}}$ & 1.48 & 1.85 & 3.06 & 1.01 & 2.20 & 1.59 & 1.65 & 1.66 & 1.54 & 1.62 & 1.63 & 1.46 & 1.61 & 2.03 \\
\hline $\mathrm{Ce} / \mathrm{Ce}^{*}$ & 1.02 & 0.98 & 1.16 & 1.04 & 1.01 & 1.03 & 1.02 & 1.02 & 1.02 & 1.02 & 1.03 & 0.99 & 1.02 & 1.02 \\
\hline $\mathrm{Eu} / \mathrm{Eu}^{*}$ & 0.83 & 1.33 & 0.82 & 0.76 & 1.02 & 0.89 & 0.96 & 0.88 & 0.96 & 0.81 & 0.92 & 0.75 & 0.87 & 1.12 \\
\hline
\end{tabular}

Note: *: volcanic rocks. 

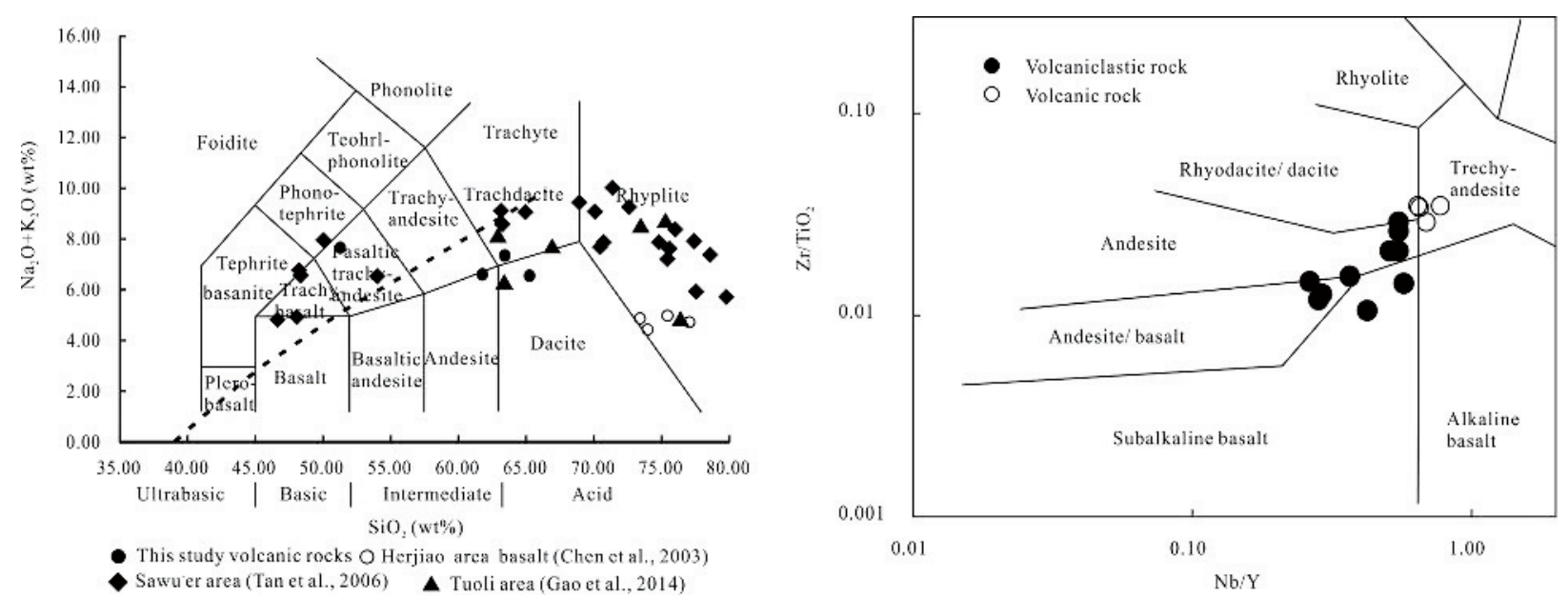

Fig. 6. All analyzed samples in TAS (total alkalis vs. silica; Le Bas et al., 1986) diagram. Alkaline versus subalkaline fields separated by the Macdonald and Katsura (1964) dashed line, and $\mathrm{Zr} / \mathrm{TiO}_{2}-\mathrm{Nb} / \mathrm{Y}$ discrimination plot of volcanic rocks and pyroclastic rocks (after Winchester and Floyd, 1977).

samples fall in the calc-alkaline field. However, all samples fall in the calc-alkaline dacite/rhyolite field in the Th-Co diagram, possibly because the major elements can be influenced by hydrothermal alteration, as reported by Hastie et al. (2007). A similar conclusion can be drawn by other diagrams, such as $\mathrm{Yb}$ vs La, $\mathrm{Zr}$ vs $\mathrm{Y}$, and Th vs $\mathrm{Yb}$. In the $\mathrm{Zr} / \mathrm{TiO}_{2}-\mathrm{Nb} / \mathrm{Y}$ diagram (Floyd and Winchester, 1978), all volcanic samples are classified as trachyandesite close to the dacite field (Fig. 6). Based on the results from the TAS diagram, the total contents of alkali elements have probably not changed greatly, indicating that major elements were affected more strongly than the trace elements (Hu et al., 2010).

The volcanic rocks show strong positive anomalies in $\mathrm{Rb}, \mathrm{K}$, and $\mathrm{U}$, moderate to weak positive anomalies in $\mathrm{Nd}$ and $\mathrm{Zr}$, strong negative anomalies in $\mathrm{Nb}, \mathrm{Ta}$, and $\mathrm{Ti}$, and moderate to weak negative anomalies in $\mathrm{Sr}$ and $\mathrm{P}$ on a primitive mantle normalized spider diagram, which is consistent with the intermediate-basic volcanic rock patterns of the Kalagang Fm. in Saur (Tan et al., 2006) and the Tuoli region (Gao et al., 2014) (Fig. 7). The total Rare Earth Element (REE) content ranges from 127.3 to 147.7 ppm, with an average of $138.8 \mathrm{ppm}$. The chondritenormalized REE distribution pattern (Fig. 8) shows a rightward slope of the Light REEs (LREEs) distributive curve and a flat Heavy REEs (HREEs) distributive curve, with weak $\mathrm{Eu}$ anomalies $\left(\mathrm{Eu} / \mathrm{Eu}^{*}: 0.8-0.9\right.$, average 0.8$)$ and no Ce anomalies (1.0-1.03, 1.02 on average). The value of $(\mathrm{La} / \mathrm{Yb})_{\mathrm{CN}}(\mathrm{CN}=$ Chondrite Normalized $)$ varies between 8.5 and 10.5 (9.5 on average), indicating that the samples are relatively enriched in LREEs.

\subsubsection{Pyroclastic rocks}

The pyroclastic rocks have relatively high LOI ranging from 10.5 to $63.0 \mathrm{wt} \%$ (22.1 $\mathrm{wt} \%$ on average), especially H-8-2 with the highest ( $63.0 \mathrm{wt} \%)$, likely because of the higher contents of organic matter, as indicated by petrologic results (Fig. 5). The pyroclastic rocks are also characterized by distinctly variable $\mathrm{SiO}_{2}$ contents ranging from 33.1 to $57.5 \%$ (average $42.4 \%$ ). Samples H-2-2 and

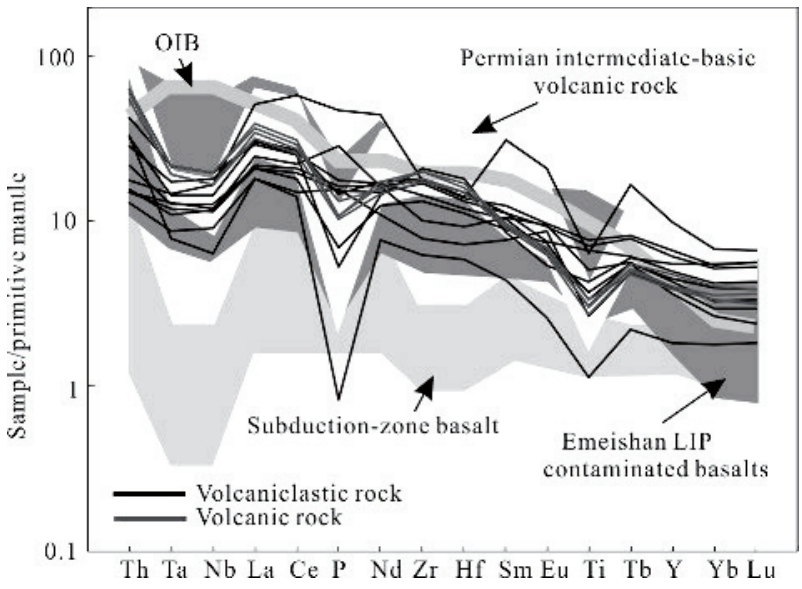

Fig. 7. Primitive mantle-normalized trace elements spider diagrams of Kalagang Formation.

Patterns for oceanic island basalts (OIB) are from Sun and McDonough (1989); The light yellow area shows the range of Permian intermendiatebasic volcanics in Saur and Tuoli aera (Kalagang Formation), date from Gao et al. (2014) and Tan et al. (2007); The light grey area shows the range of subduction zone basalts, with the lower and upper limits being defined by "average" low-K and high-K basalts, respectively (Tatsumi and Eggins, 1995); The deep grey area shows the range of Late Permian contaminated continental basaltic lava from the Emishan large igneous province (Xia, 2014)

H-9 have relatively higher $\mathrm{SiO}_{2}(57.5$ and $51.4 \mathrm{wt} \%)$ and $\mathrm{CaO}$ contents (2.4 and $3.3 \mathrm{wt} \%)$, respectively, which may be attributed to the high proportions of quartz and calcite, which is consistent with the abundant calcite veins commonly observed by petrological analysis (Fig. 3 ). The $\mathrm{Al}_{2} \mathrm{O}_{3}$ content in these samples ranges from 11.0-17.9 $\mathrm{wt} \%(15.3 \%$, average $)$, and the $\mathrm{TiO}_{2}$ content ranges from 0.6 to $1.7 \mathrm{wt} \%$.

In the primitive mantle normalized trace element spider diagram, the samples show strong positive anomalies in Large Ion Lithophile Elements (LILEs) (e.g., Rb, K, and $\mathrm{Pb}$ ) and strong negative anomalies in High Field Strength Elements (HFSEs) (e.g., Nb, Ta, Ti). In addition, P has slightly positive and negative anomalies (Fig. 7). The 


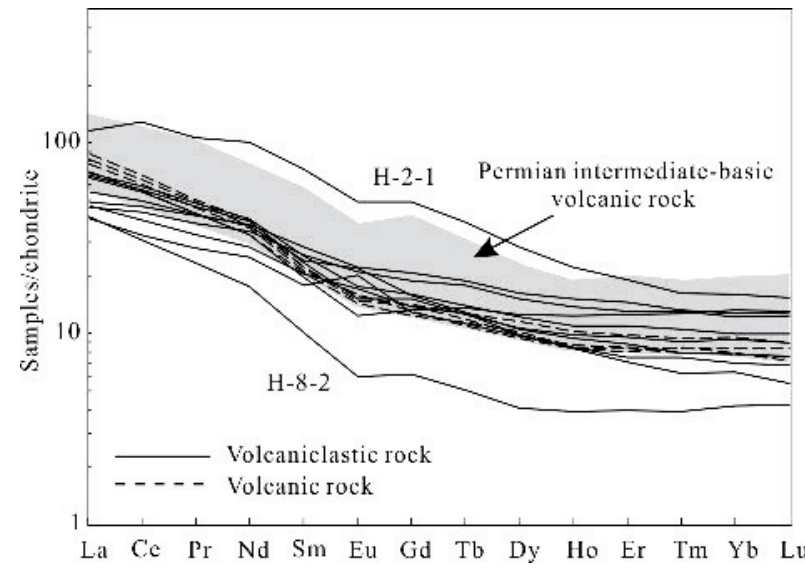

Fig. 8. Chondrite normalized trace element spider diagrams for the Kalagang Formation.

Data of Permian intermendiate-basic volcanics in Saur and Tuoli aera (Kalagang Formation) are plotted for comparison (Gao et al., 2014; Tan et al., 2007).

samples display highly variable $\Sigma$ REE contents, from 67.0 to $309.4 \mathrm{ppm}$ (average $74.8 \mathrm{ppm}$ ), among which $\mathrm{H}-8-2$ (67.0 ppm) shows a remarkable depletion, whereas H-2-1 (309.4 ppm) shows a strong enrichment. The chondritenormalized REE distribution patterns are characterized by slight LREEs enrichment and a relatively weak fractionated flat pattern of HREEs. The samples have no $\mathrm{Eu}$ and $\mathrm{Ce}$ anomalies $\left(\mathrm{Eu} / \mathrm{Eu}^{*}\right.$, average $0.9 ; \mathrm{Ce} / \mathrm{Ce}^{*}: 1.0$ 1.2 , average 1.0), except for sample $\mathrm{H}-8-2$ with a negative anomaly $\left(\mathrm{Eu} / \mathrm{Eu}^{*}=0.8\right)$ and sample $\mathrm{H}-1-2$ with a slightly positive anomaly $\left(\mathrm{Eu} / \mathrm{Eu}^{*}=1.3\right)($ Fig. 8).

\section{Discussion}

\subsection{Weathering and alteration effects}

In the present study, all the samples have higher LOI contents, which might be caused by alteration effects (in volcanic rocks) or higher content of organic matter content (in pyroclastic rocks). In accordance with the petrological research, plagioclase was the most easily altered to smectites, carbonate, and clay minerals in volcanic rocks (Fig. 4). The pyroclastic rocks generally tend to contain higher contents of organic matter, causing elevated LOI values. Generally, some major elements (e.g., Ti, P, Fe, and $\mathrm{Mn}$ ), the HFSEs, REEs, Th, and transition elements are not readily transported by hydrothermal alteration, and thus, those elements may exhibit no obvious correlation with LOI (Zhou, 1999; Wang et al., 2006; Liu et al., 2018), whereas the $\mathrm{Al}_{2} \mathrm{O}_{3}, \mathrm{SiO}_{2}$, and $\mathrm{Rb}$ contents clearly decrease with increasing LOI, implying that their original contents were modified by alteration.

The chemical index of alteration $\left(\mathrm{CIA}=\left[\mathrm{Al}_{2} \mathrm{O}_{3} /\left(\mathrm{Al}_{2} \mathrm{O}_{3}\right.\right.\right.$ $\left.\left.+\mathrm{CaO}^{*}+\mathrm{Na}_{2} \mathrm{O}+\mathrm{K}_{2} \mathrm{O}\right)\right] \times 100$, where $\mathrm{CaO} *$ represents the $\mathrm{CaO}$ only incorporated into silicate minerals) is considered to be a useful parameter in inferring the weathering degree of source rocks (Nesbitt and Young, 1982). However, the source rocks can be affected by recycling, which will influence CIA values. Cox et al. (1995) proposed the index of compositional variability ( $\mathrm{ICV}=$ $\left.\left(\mathrm{Fe}_{2} \mathrm{O}_{3}+\mathrm{K}_{2} \mathrm{O}+\mathrm{Na}_{2} \mathrm{O}+\mathrm{CaO}+\mathrm{MgO}+\mathrm{MnO}+\mathrm{TiO}_{2}\right) / \mathrm{Al}_{2} \mathrm{O}_{3}\right)$ to determine whether the source rocks have been recycled or not. In this study, the ICV values (1.3-4.6, average 2.6) show that the source rocks have not been recycled. When plotted in the A-CN-K $\left(\mathrm{Al}_{2} \mathrm{O}_{3}-\left(\mathrm{CaO} *+\mathrm{Na}_{2} \mathrm{O}\right)-\mathrm{K}_{2} \mathrm{O}\right)$ ternary diagram (Fig. 9), the sediments exhibit positions commensurate with low CIA values (49.3-69.3, average 59.3 ), and most of the samples yield a series of CIA values distributed along a straight line (ideal weathering trend) parallel to the A-CN sideline (Nesbitt and Young, 1982; McLennan, 1993). However, some data points plot on a line deviating from the theoretical trend, suggesting $\mathrm{K}_{2} \mathrm{O}$ addition as a result of diagenetic K-metasomatism (conversion of kaolinite to illite), so it is necessary to make corrections for this (Fedo et al., 1997; Rieu et al., 2007; Yan et al., 2010) (Fig. 9). The corrected CIA values show the same weathering intensity (Nesbitt and Young., 1989). The mineralogical variation can also provide some evidence for the weathering intensity. There is abundant plagioclase and little to no clay minerals in the pyroclastic rocks, especially in the carbon-bearing tuffaceous mudstone, which also indicates a low to moderate degree of chemical weathering, consistent with the CIA values (Fig. 5).

During the process of weathering or recycling, $U$ is more likely to migrate than Th, resulting in an increase in the $\mathrm{Th} / \mathrm{U}$ ratio. McLennan et al., (1993) proposed that a $\mathrm{Th} / \mathrm{U}$-Th diagram can be used to discriminate the degree of sediment recycling and heavy-mineral sorting. The ratios of the pyroclastic rocks range from 1.89 to 3.54 with an average of 2.95, which is lower than that of the UCC [Up Continental Crust] (3.8, Taylor and McLennan, 1985). In the Th/U-Th diagram (Fig. 10), however, the points do not follow the normal weathering trend and almost all samples plot close to the field of depleted mantle source,

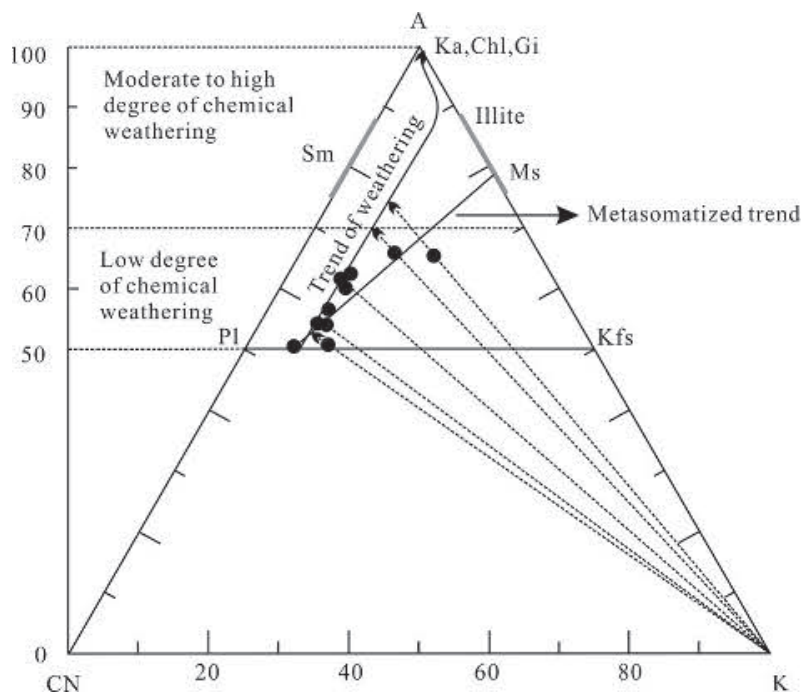

Fig. 9. Chemical compositional variations in Kalagang Formation in ternary A-CN-K plot and associated chemical index of alteration (CIA) variations. Correction for Kmetasomatism is made by projecting data points back to the ideal weathering pathway from $\mathrm{K}$-apex (dashed arrows).

Ka, kaolinite; Chl, chlorite; Gi, Gibbsite; Sm, smectite; Ms, muscovite; Pl, plagioclase; Kfs, K-feldspar (after Nesbitt and Young, 1984; Cox et al., 1995). 
indicating that these sediments were derived from source rocks with a low degree of weathering or from sediment with very little recycling (Meinhold et al., 2007; Xiang et al., 2015). The $\mathrm{Th} / \mathrm{Sc}$ ratio characterizes the average provenance, whereas an increase in the $\mathrm{Zr} / \mathrm{Sc}$ ratio alone indicates significant sediment reworking, consistent with zircon enrichment (McLennan, 1993). The Th/Sc and $\mathrm{Zr} /$ Sc of pyroclastic rocks have a significant positive correlation in the study area $\left(R^{2}=0.88\right.$, Fig. 11$)$, revealing that the geochemical changes are determined by the sediment-region rocks rather than by sedimentary recycling (Cullers, 1994; Li et al., 2015).

\subsection{Crustal contamination, and partial melting}

The samples, including volcanic and pyroclastic rocks, have relatively low contents of $\mathrm{MgO}$ (average $1.65 \mathrm{wt} \%$ and $3.45 \mathrm{wt} \%$ ) and compatible elements, including $\mathrm{Ni}$ (average 32.0 and $57.3 \mathrm{ppm}$ ) and $\mathrm{Cr}$ (average 45.8 and $64.7 \mathrm{ppm}$ ), respectively, possibly suggesting that the samples represent evolved magmas rather than primitive magmas directly generated by partial melting of mantle sources (He et al., 2015). The positive correlation between $\mathrm{SiO}_{2}$ and $\mathrm{Th} / \mathrm{La}\left(R^{2}=0.40\right)$ and $\mathrm{U} / \mathrm{Nb}\left(R^{2}=0.36\right)$ indicates extensive crustal contamination (Wang et al., 2011; Tang et al., 2013; Ma et al., 2015). In addition, the volcanic and pyroclastic samples are characterized by elevated contents of LILEs ( $\mathrm{Rb}$ and $\mathrm{Pb})$ and LREEs, strong negative

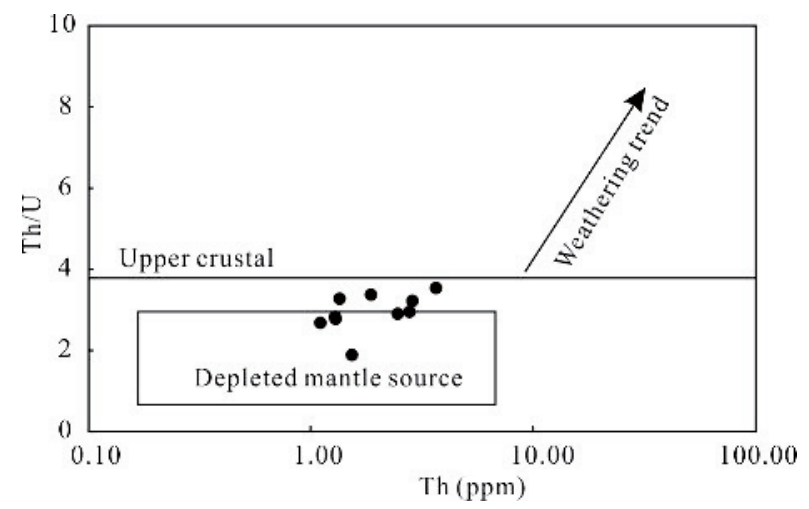

Fig. 10. Th/U vs. Th bivariate plot of Kalagang Formation pyroclastic rocks (McLennan et al., 1993).

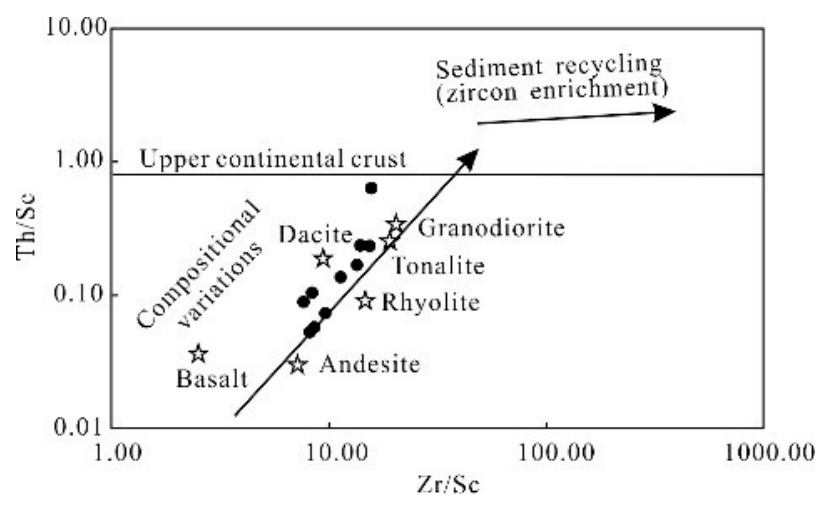

Fig. 11. Th/Sc-Zr/Sc diagram after McLennan et al. (1993). Data of tonalite, granodiorite, rhyolite and andesite are from Condie (1993), data of basalt and dacite are from Roser et al. (2002) and Xiang et al. (2015). anomalies in HFSEs ( $\mathrm{Nb}, \mathrm{Ta}$, and Ti), slightly or no negative $\mathrm{Eu}$ anomalies and $\mathrm{Nb} / \mathrm{La}$ ratio $<1$ (average 0.53 and 0.52 , respectively), which appear to indicate crustal contamination (Condie, 2001; Kieffer et al., 2004). However, these abovementioned geochemical features might also have been affected by the tectonic environment. For example, the enrichment of LILEs and LREEs in the volcanic rocks might also have been caused during the subduction process by low-temperature partial melting in the source area (Pearce et al., 1990; Kürüm et al., 2017); low contents of $\mathrm{Nb}, \mathrm{Ta}$ and $\mathrm{Ti}$ are also characteristic of island arc and active continental margin basalts (Pearce, 1982; Keppler, 1996; You et al, 1996; Xia, 2014; Xia and Li, 2019).

The ratios of $\mathrm{Nb} / \mathrm{U}, \mathrm{Ta} / \mathrm{U}$ and $\mathrm{Ce} / \mathrm{Pb}$ are sensitive indicators for identifying contamination and tectonic environments (Hofmann et al., 1986; Hofmann, 1997; Jahn et al., 1999; Jiang et al., 2006; Sun et al., 2008; Tang et al., 2012, 2017). All samples show lower ratios of $\mathrm{Nb} / \mathrm{U}$ (average 6.05 and 14.89 , respectively), $\mathrm{Ta} / \mathrm{U}$ (average 0.39 and 0.86 , respectively), and $\mathrm{Ce} / \mathrm{Pb}$ (average 6.45 and 9.16, respectively) than MORB, OIB and the mean value of crust, and these ratios cannot be caused easily by crustal contamination (Shu et al., 2017). On the $\mathrm{Nb} / \mathrm{Th}, \mathrm{Ta} / \mathrm{Th}$ and $\mathrm{Th} / \mathrm{Yb}$ primitive mantle-normalized ratio plots (Fig. 12), the samples are controlled by the N-MORB, upper crust (UC) and lower crust (LC) mixing trend lines. The volcanic rocks and sample $\mathrm{H}-8-2$ are more closely related to the UC trend line, whereas the pyroclastic rocks are more similar to the LC trend line (Tang et al., 2017). This also cannot be explained simply by crustal contamination and that may be inherited from their magma sources. Zhou et al. (2006) also confirmed that the Permian volcanic rocks in the Saur area did not originate from the residual melt of mantle-derived basalt magma after the differentiation of basic plagioclase, but from crust-mantle mixed source magma.

In the diagram of La vs. La/Sm (Treuil and Varet, 1973), the $\mathrm{La} / \mathrm{Sm}$ ratio increased with the increasing $\mathrm{La}$ content $\left(R^{2}=0.6\right)$. Therefore, the compositional variations of the pyroclastic rocks are likely to have resulted from partial melting (Fig. 13). Correspondingly, Tan et al. (2006) analyzed the trace elements of the Permian volcanic rocks in the Saur area, and concluded that the mechanism of formation of the basic and intermediate volcanic rocks was mainly equilibrium partial melting, and that magmatic fractional crystallization was not significant, whereas the rock-forming processes of intermediate-acidic volcanic rocks were influenced by both partial melting and fractional crystallization. Ratios such as $\mathrm{Zr} / \mathrm{Y}$ and $\mathrm{Zr} / \mathrm{Nb}$ are used to determine the degree of partial melting or the effects of partial melting (Fitton et al., 1988). Our samples have low $\mathrm{Zr} / \mathrm{Y}$ and medium-high $\mathrm{Zr} / \mathrm{Nb}$ ratios, indicating moderate degree partial melting.

\subsection{Provenance}

Volcanic material (volcanic lithic fragments, crystal clast, and glass) represents a high proportion of the pyroclastic rocks, indicating a primary volcanic rock source. The lithic tuff contains abundant basalt and andesite lithic fragments. Also, the majority of these lithic 

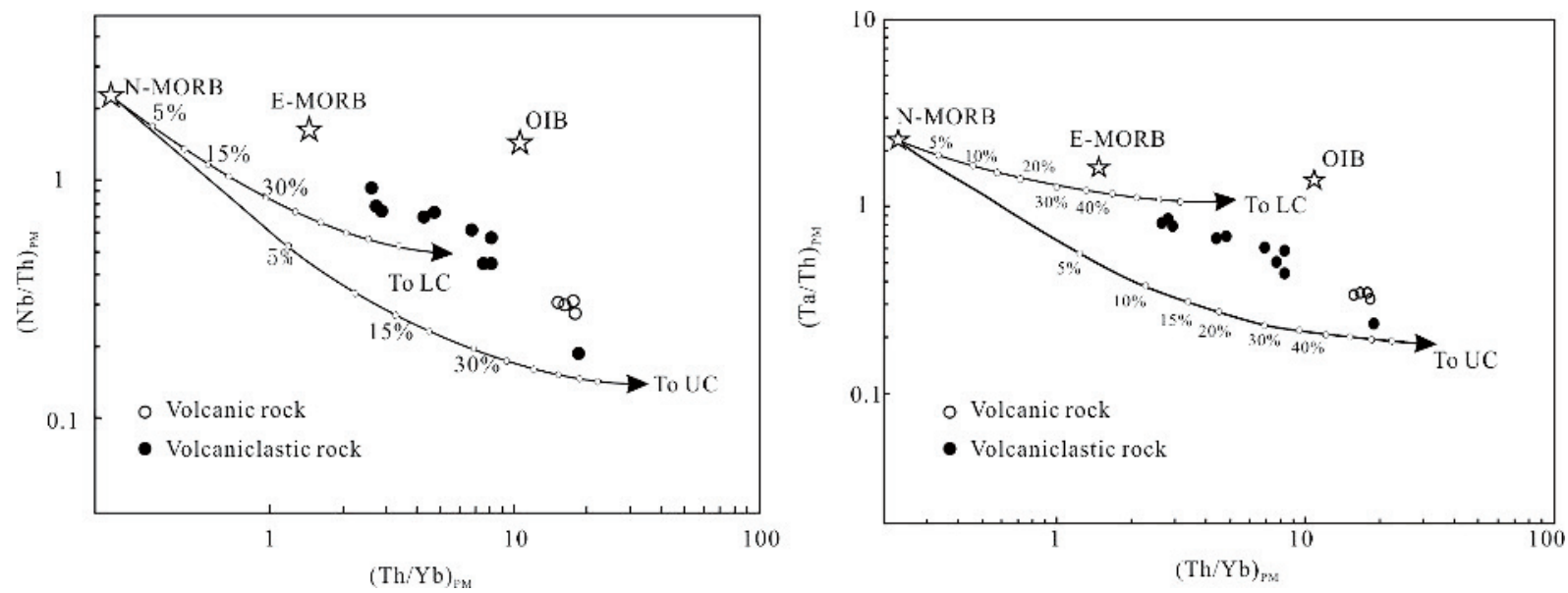

Fig. 12. Trace element ratio diagrams of Kalagang Formation pyroclastic rocks and volcanic rocks after Dongmei Tang (2017). The primitive mantle, N-MORB, E-MORB and OIB values are from Sun and McDonough (1989), and trace element values of the upper crust (UC) and lower crust (LC) are from Rudnick and Gao (2003).
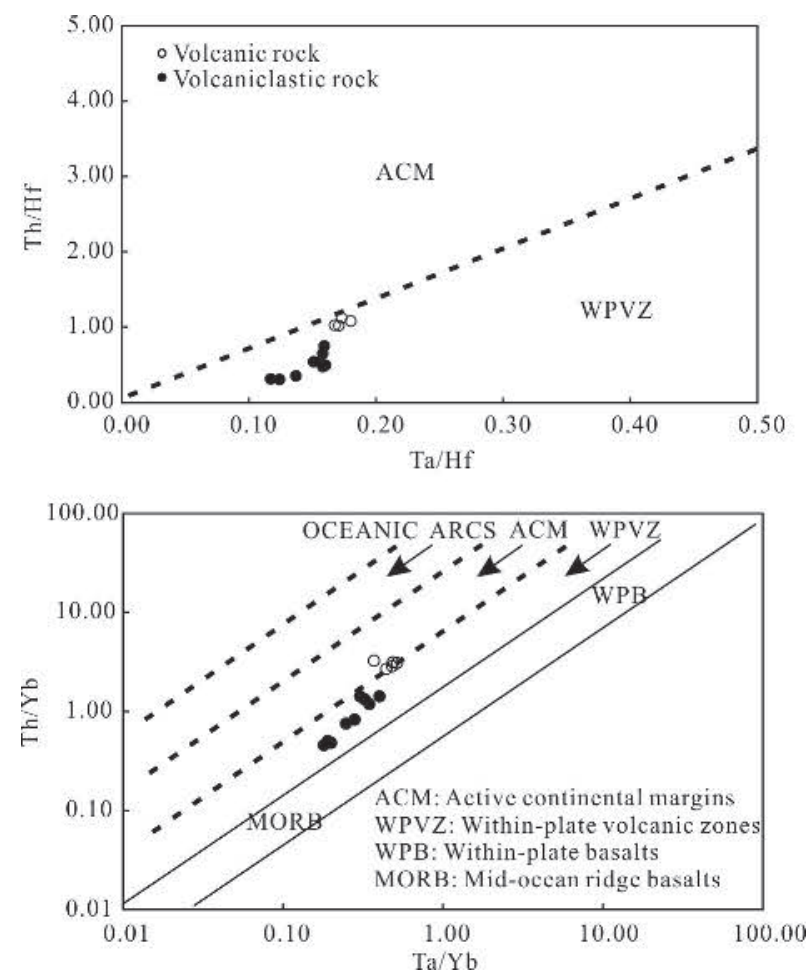

Fig. 13. Discrimination plots of $\mathrm{Th} / \mathrm{Yb}$ versus $\mathrm{Ta} / \mathrm{Yb}$ (after Gorton and Schandl, 2000) and Th/Hf versus Ta/Hf (after Schandl and Gorton, 2002) for tectonic settings.

fragments appear angular to subangular in shape. All the petrological features reflect short-distance transport of basaltic and andesite materials from the sediment-source region. In addition, some elements, such as REEs, HFEEs and transition metal elements (e.g. $\mathrm{Co}, \mathrm{Ni}, \mathrm{V}, \mathrm{Cr}, \mathrm{Sc}$ ), are considered immobile during weathering, sedimentary transport, deposition, diagenesis, and most intense hydrothermal alteration (Cullers et al., 1988; Taylor and McLennan, 1985; McLennan et al., 1993; Condie, 1993; Zhou, 1999; Hawkesworth et al., 1997; Wang and Xu 2006; Xiang et al., 2015). Therefore, these elements are particularly useful in discriminating the nature of the parent rock for clastic sedimentary rocks.

Transition metal element contents are higher in mafic and ultramafic rocks and lower in felsic rocks, while HFSEs (e.g. Zr, Th, La, Y, Nb) are abundant in felsic rocks (Asiedu et al., 2017). The pyroclastic rocks have relatively high contents of $\mathrm{Cr}$ (29.2-130.6 ppm, average $64.7 \mathrm{ppm})$, Ni (28.0-86.4 ppm, average $57.3 \mathrm{ppm})$, and low $\mathrm{Cr} / \mathrm{Ni}$ ratio $(<1.3)$, indicating input of mafic volcanic rocks rather than ultramafic rocks from the source area. The $\mathrm{Ti} / \mathrm{Nb}$ ratio of the source rock generally does not change during weathering and transport and thus can be used to indicate the type of source rocks, with a $\mathrm{Ti} / \mathrm{Nb}$ ratio greater than 300 indicative of the input of basic volcanic rocks and less than 300 indicative of the input of acidic volcanic rocks (Jenchen and Rosenfeld, 2002). The ratio of $\mathrm{Ti} / \mathrm{Nb}$ in the pyroclastic rocks is higher than 300 , with an average of 669 , indicating the input of basic compositions. In addition, the ratios of $\mathrm{Th} / \mathrm{Sc}, \mathrm{Th} / \mathrm{Co}, \mathrm{Th} /$ $\mathrm{Cr}$ and $\mathrm{La} / \mathrm{Co}$ are significantly different between mafic and felsic source rocks (Cullers, 2000; Zaid, 2015; Asiedu et al., 2017) and can be used to determine the provenance of rocks (Armstrong-Altrin et al., 2013). The source rocks of the pyroclastic rocks in the study area are similar to mafic volcanic rocks, except for sample H-8-2, which is similar to felsic rocks (Table 2). Classification diagrams, such as $\mathrm{Zr} / \mathrm{TiO}_{2}-\mathrm{Nb} / \mathrm{Y}$, have been widely used to identify source rock types. In this diagram, only sample H-8-2 falls into the rhyodacite/dacite area, whereas the other samples fall into the andesite and sub-alkaline basalt area (Fig. 6).

The REE content, distribution pattern and Eu anomaly can be used as important indicators for the identification of sedimentary source rocks (Taylor and McLennan, 1985; Xiang et al., 2015; Asiedu et al., 2017). Felsic volcanic rocks have a high ratio of LREE/HREE and a strong negative Eu anomaly, whereas mafic volcanic rocks have a low LREE/HREE ratio and no negative Eu anomalies (Cullers, 1994, 2000; Yan et al., 2012). The REE distribution pattern of pyroclastic rocks in Harjiao and the adjacent region is similar to that of intermediate-basic volcanic rocks, with low LREE/HREE ratios (1.79-3.63, average 2.57) and weak $\mathrm{Eu}$ anomalies (Eu/Eu*: 0.75- 
Table 2 Element ratio ranges of pyroclastic rocks compared to the ratios of sedimentary rocks derived from felsic rocks and mafic rocks

\begin{tabular}{|c|c|c|c|c|c|c|c|c|c|c|c|c|c|}
\hline & H-1-2 & H-2-1 & H-2-2 & H-3-2 & H-6 & $\mathrm{H}-7$ & H-8-1 & H-8-2 & H-9 & $\mathrm{H}-10$ & $\begin{array}{c}\text { Range of } \\
\text { sediments from } \\
\text { felsic sources }\end{array}$ & $\begin{array}{c}\text { Range of } \\
\text { sediments from } \\
\text { mafic sources }\end{array}$ & $\begin{array}{c}\text { Average } \\
\text { UCC }\end{array}$ \\
\hline $\mathrm{Th} / \mathrm{Sc}$ & 0.10 & 0.07 & 0.23 & 0.17 & 0.06 & 0.24 & 0.05 & 0.64 & 0.14 & 0.09 & $0.84-20.5$ & $0.55-0.22$ & 0.79 \\
\hline $\mathrm{Th} / \mathrm{Co}$ & 0.08 & 0.05 & 0.26 & 0.08 & 0.04 & 0.17 & 0.03 & 0.80 & 0.08 & 0.06 & $0.67-19.4$ & $0.04-1.40$ & 0.63 \\
\hline $\mathrm{Th} / \mathrm{Cr}$ & 0.02 & 0.01 & 0.06 & 0.03 & 0.03 & 0.05 & 0.04 & 0.07 & 0.03 & 0.01 & $0.13-2.70$ & $0.02-0.05$ & 0.13 \\
\hline $\mathrm{Eu} / \mathrm{Eu}^{*}$ & 1.33 & 0.81 & 0.76 & 1.01 & 0.96 & 0.80 & 0.92 & 0.75 & 0.86 & 1.12 & $0.32-0.94$ & $0.7-1.2$ & 0.63 \\
\hline$(\mathrm{La} / \mathrm{Lu})_{\mathrm{CN}}$ & 5.95 & 7.51 & 5.05 & 8.60 & 3.78 & 7.61 & 3.80 & 9.68 & 6.99 & 7.26 & $3.0-27.0$ & $1.1-7.0$ & 9.73 \\
\hline $\mathrm{La} / \mathrm{Co}$ & 0.94 & 1.06 & 1.46 & 0.63 & 0.45 & 1.26 & 0.41 & 3.53 & 0.71 & 0.71 & $1.4-22.4$ & $0.14-0.38$ & 1.76 \\
\hline
\end{tabular}

Data from Cullers et al. (2000); Asiedu et al. (2017); Zaid et al. (2015).

1.33), except for sample H-8-2 with the highest LREE/ HREE ratio (3.63) and the lowest $\mathrm{Eu} / \mathrm{Eu}^{*}$ value (0.73), indicative of intermediate-acidic volcanic rocks. In addition, sample H-8-2, from the roof of a coal seam, has the highest value of LOI (63 wt\%), and its geochemical characteristics resemble the underlying coal seam, indicating that they most likely have the same source rock.

\subsection{Tectonic setting and implications}

The elevated concentrations of LILEs and LREEs, along with the negative anomalies of HFSEs (e.g. Nb and $\mathrm{Ta}$ ), as well as the absence of significant Eu and $\mathrm{Ce}$ anomalies, most likely indicate an intraplate affinity, which is similar to the post-collisional volcanic rocks in the West and East Junggar (Tan et al., 2006; Li et al., 2014, 2015; Su et al., 2012; Xu et al., 2013). In some discriminant diagrams, such as $\mathrm{Th} / \mathrm{Yb}-\mathrm{Ta} / \mathrm{Yb}$ and $\mathrm{Th} / \mathrm{Hf}-$ $\mathrm{Ta} / \mathrm{Hf}$ (Gorton and Schandl, 2000), which are widely used to distinguish the tectonic setting of intermediate rocks, all the pyroclastic rocks fall in the within-plate volcanic zones (WPVZ), whereas the volcanic rocks fall in the boundary between within-plate volcanic zones and active continental margin (ACM) (Fig. 14). The similarity is that in the $\mathrm{Zr} / \mathrm{Y}$ -Zr diagram (Pearce and Norry, 1979), all samples fall into or near the within-plate basaltic (WPB) field (Fig. 15), however, they plot in the arc-related field in other discriminant diagrams using $\mathrm{Nb}, \mathrm{Ta}, \mathrm{Ti}$ or $\mathrm{Th}$ as discriminating factors. These anomalous geochemical patterns may be explained by crustal contamination or variable degree of fractional crystallization and melting rather than by tectonic setting. For example, contamination by continental crust or lithosphere can impart subduction-like signatures and lead to the misidentification of contaminated continental intraplate basaltic rocks as arc-related ones (Xia et al., 2008, 2014; Ernst et al., 2005; Jourdan et al., 2007; Neumann et al., 2011). Xia et al. $(2016,2019)$ proposed that contaminated continental intraplate basalts are characterized by pronounced negative $\mathrm{Nb}, \mathrm{Ta}$, and $\mathrm{Ti}$ anomalies, but the concentrations of incompatible trace elements are conspicuously higher than those of subduction-zone basalts. Therefore, for basalts contaminated by the crust or lithosphere, diagrams often fail to indicate accurately the corresponding tectonic setting (Xia et al., 2014). Our samples show distinct negative $\mathrm{Nb}$ and $\mathrm{Ta}$, whereas the incompatible elements are significantly higher in the samples than in subduction zone basalts (Fig. 7), which is similar to the distribution pattern of contaminated basalts in the Emeishan large igneous province (Xia et al., 2014).

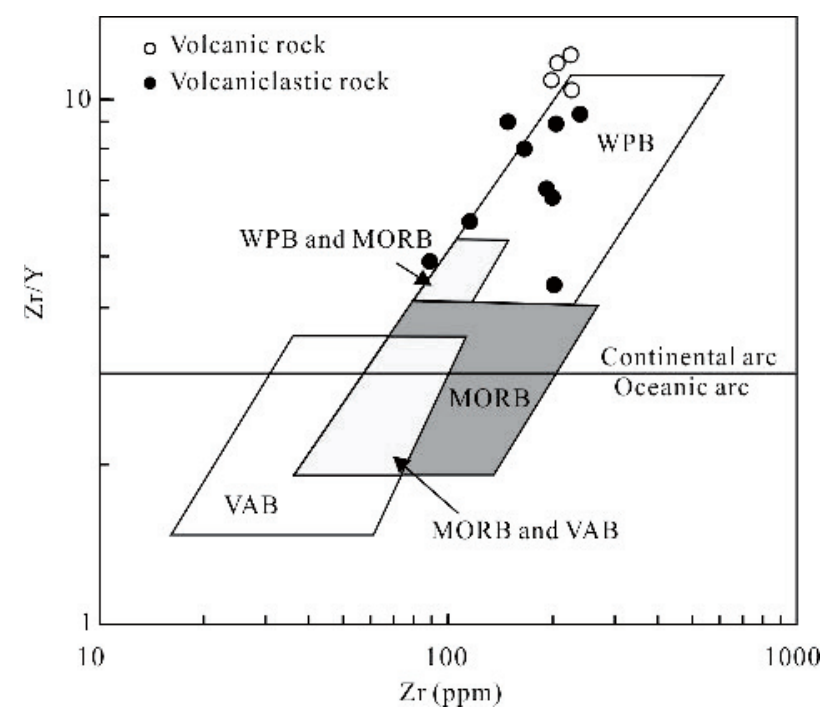

Fig. 14. Zr/Y-Zr diagram after Pearce and Norry (1979), the continental and oceanic arc fields defined by Pearce (1982 or 1983).

Vertically from bottom to top, the borehole ZKH1205 records two phases of volcanism according to the petrological features during the early Permian. The major source rocks might have been derived from periodic eruptions of volcanic rocks (basalt and andesite). The adjacent region also features a contemporary basalt that was generated in the extensional stage of the postcollisional setting with significant bimodal features. Furthermore, the widely generated contemporary A-type granites provide additional evidence for the extensional regime (Zhou et al., 2008). As noted above, the IrtyshZaysan suture zone formed in the Late Carboniferous (Chen et al., 2010), indicating the termination of collision. In fact, the plutons in West Junggar, East Junggar, southern Chinese Altai, and the Chinese Western Tianshan that formed in the latest Late Carboniferous to Middle Permian, were all generated in a post-collisional setting (Chen et al., 2010). Therefore, with the closure of the Irtysh-Zaysan Ocean and the collision between the Siberian and Kazakhstan-Junggar continents or because of the amalgamation between the Altai and Zharma-Saur terranes, the Ha'erjiao region entered a post-collisional extensional stage in the Early Permian.

\section{Conclusions}

Based on the results and the reported data of our study, 
we estimate the provenance and tectonic setting of the Lower Permian Kalagang Formation rocks in the Jimunai Basin and provide new evidence for the tectonic evolution of the northern West Junggar region.

The pyroclastic rocks studied have high contents of loss on ignition (LOI), which might be caused by high contents of organic matter. The petrological characteristics, abundant presence of plagioclase and absence of clay minerals, together with geochemical parameters such as a low value of the chemical index of alteration (CIA) and the ratio of $\mathrm{Rb} / \mathrm{Sr}$, indicate a relatively weak chemical weathering intensity. The $\mathrm{Th} / \mathrm{Sc}$ and $\mathrm{Zr} / \mathrm{Sc}$ ratios of the pyroclastic rocks have a strong positive correlation $\left(R^{2}=\right.$ 0.88 ), indicating that geochemical variation was dominated by the composition of the source materials and not by sediment recycling.

The pyroclastic rocks also show that there are two types of source rocks: (1) intermediate-basic volcanic rock with high $\mathrm{Ti} / \mathrm{Nb}$ ratios, low $\mathrm{Th} / \mathrm{Sc}$ and light (LREE)/heavy (HREE) rare earth element ratios, and weak Eu anomalies (Eu/Eu*: 0.75-1.33); and (2) felsic volcanic rocks based on one sample (H-2), which is completely different from others but similar to the underlying coals, with the highest LREE/HREE ratio and lowest $\mathrm{Eu} / \mathrm{Eu}^{*}$ value, and falls into the rhyodacite/dacite area on the $\mathrm{Zr} / \mathrm{TiO}_{2}-\mathrm{Nb} / \mathrm{Y}$ diagram.

The samples analyzed in this study are enriched in LILEs and LREEs, have negative anomalies in some HFSEs (e.g., $\mathrm{Nb}$ and $\mathrm{Ta}$ ) and no significant $\mathrm{Eu}$ and $\mathrm{Ce}$ anomalies, indicating an intraplate affinity, which is similar to those of the post-collisional volcanic rocks reported from the West and East Junggar terranes. Because of crustal contamination, all the pyroclastic rocks fall in or near the within-plate volcanic zones (WPVZ) or within-plate basaltic (WPB) in the discriminant diagrams used, which do not use $\mathrm{Nb}, \mathrm{Ta}$ and $\mathrm{Ti}$ as discriminating factors. This geochemical pattern is similar to that of the latest Upper Carboniferous-Middle Permian basalts in the adjacent region, which were generated in a post-collisional setting.

\section{Acknowledgments}

This research was funded by the National Science Foundation for Young Scientists of China (No. 41602176) and Key Laboratory of Tectonics and Petroleum Resources (TPR-2018-16). The authors would like to express sincere thanks to the Xinjiang Bureau of Prospecting and Development of Geology and Mineral Resources for assistance with sampling. Susan Turner (Brisbane) assisted with English language.

\section{Manuscript received May 10, 2019 accepted Oct. 24, 2019 associate EIC: XU Jifeng edited by FEI Hongcai}

\section{References}

Armstrong-Altrin, J.S., Nagarajan, R., Madhavaraju, J., RosalezHoz, L., Lee, Y.I., Balaram, V., Cruz-Martinez, A., and Avila -Ramirez, G., 2013. Geochemistry of the Jurassic and upper Cretaceous shales from the Molango Region, Hidalgo, Eastern Mexico: implications of source-area weathering, provenance, and tectonic setting. Comptes Rendus Geoscience, 345: 185202.

Asiedu, D.K., Asong, S., Atta-Peters, D., Sakyi, P.A., Su, B.-X., Dampare, S.B., and Anani, C.Y., 2017. Geochemical and Ndisotopic compositions of juvenile-type Paleoproterozoic Birimian sedimentary rocks from southeastern West African Craton (Ghana): Constraints on provenance and tectonic setting. Precambrian Research, 300: 40-52.

Bas, M.L., Maitre, R.L., Streckeisen, A., Zanettin, B., and IUGS Subcommission on the Systematics of Igneous Rocks, 1986. A chemical classification of volcanic rocks based on the total alkali-silica diagram. Journal of Petrology, 27(3): 745-750.

Brookfield, M.E., 2000. Geological development and Phanerozoic crustal accretion in the western segment of the southern Tien Shan (Kyrgyzstan, Uzbekistan and Tajikistan). Tectonophysics, 328: 1-14.

Buckman, S., and Aitchison, J.C., 2004. Tectonic evolution of Paleozoic terranes in West Junggar, Xinjiang, NW China. In: Malpas, J., Fletcher, C.J.N., Aitchison, J.C. (eds.), Aspects of the Tectonic Evolution of China. Geological Society of London, Special Publication, 226: 101-129.

Buslov, M.M., Fujiwara, Y., Iwata, and K., Semakov, N.N., 2004. Late Paleozoic-Early Mesozoic geodynamics of Central Asia. Gondwana Research, 7: 791-808.

Buslov, M.M., Safonova, I.Yu., Watanabe, T., Obut, O., Fujiwara, Y., Iwata, K., Semakov, N.N., Sugai, Y., Smirnova, L.V., and Kazansky, A.Yu, 2001. Evolution of the PaleoAsian Ocean (Altai-Sayan region, Central Asia) and collision of possible Gondwana-derived terranes with the southern marginal part of the Siberian continent. Geosciences Journal, 5: 203-224.

Cai, K., Sun, M., Yuan, C., Xiao, W., Zhao, G., Long, X., and $\mathrm{Wu}, \mathrm{F} ., 2012$. Carboniferous mantle-derived felsic intrusion in the Chinese Altai, NW China: implications for geodynamic change of the accretionary orogenic belt. Gondwana Research, 22: 681- 698 .

Chen, B., and Jahn, B.M., 2004. Genesis of post-collisional granitoids and basement nature of the Junggar Terrane, NW China: Nd-Sr isotope and trace element evidence. Journal of Asian Earth Sciences, 23: 691-703.

Chen, J.F., Han, B.F., Ji, J.Q., Zhang, L., Xu, Z., He, G.Q., and Wang, T., 2010. Zircon U-Pb ages and tectonic implications of Paleozoic plutons in northern West Junggar, North Xinjiang, China. Lithos, 115: 137-152.

Chen, J.F., Han, B.F., Ji, J.Q., Zhang, L., Xu, Z., and He, G.Q., 2010. Zircon U-Pb ages and tectonic implications of Paleozoic plutons in northern west Junggar, North Xinjiang, China. Lithos, 115(1-4): 137-152.

Condie, K.C., 1993. Chemical composition and evolution of the upper continental crust: contrasting results from surface samples and shales. Chemical Geology, 104: 1-37.

Condie, K.C., 2001. Mantle Plumes and Their Record in Earth History. Cambridge University Press, Oxford. UK, 1-306.

Conticelli, S., Guarnieri, L., Farinelli, A., Mattei, M., Avanzinelli, R., Bianchini, G., Boari, E., Tommasini, S., Tiepolo, M., Prelević, D., and Venturelli, G., 2009. Trace elements and $\mathrm{Sr}-\mathrm{Nd}-\mathrm{Pb}$ isotopes of $\mathrm{K}$-rich, shoshonitic, and calc-alkaline magmatism of the Western Mediterranean Region: genesis of ultrapotassic to calc-alkaline magmatic associations in a post-collisional geodynamic setting. Lithos, 107: 68-92

Cox, R., Lowe, D.R., Cullers, and R.L., 1995. The influence of sediment recycling and basement composition on evolution of mudrock chemistry in the Southwestern United-States. Geochimica et Cosmochimica Acta, 59: 2919-2940.

Cullers, R.L., 1994. The controls on the major and trace element variation of shale, siltstones, and sandstones of Pennsylvanian -Permian age from uplifted continental blocks in Colorado to platform sediment in Kansas, USA. Geochimica et Cosmochimica Acta, 58: 4955-4972.

Cullers, R.L., 2000. The geochemistry of shales, siltstones and sandstones of Pennsylvanian-Permian age, Colorado, USA: implications for provenance and metamorphic studies. Lithos 51: 181-203.

Cullers, R.L., Basu, A., and Suttner, L., 1988. Geochemical 
signature of provenance in sandsize material in soils and stream sediments near the Tobacco Root batholiths, Montana, USA. Chemical Geology, 70: 335-348.

Daniel, K.A., Samuel, A., Atta-Peters, D., Asamoah Sakyi, P., Su, B.X., Samuel, B.D., and Chris, Y.A., 2017. Geochemical and Nd-isotopic compositions of juvenile-type Paleoproterozoic Birimian sedimentary rocks from southeastern West African Craton (Ghana): Constraints on provenance and tectonic setting. Precambrian Research, 300: $40-52$.

Dobretsov, N.L., 2003. Evolution of structures of the Urals, Kazakhstan, Tien Shan, and Altai-Sayan region within the Ural-Mongolian fold belt (Paleoasian ocean). Russian Geology and Geophysics, 44: 3-26.

Duggen, S., Hoernle, K., van den Bogaard, P., and GarbeSchönberg, D., 2005. Post-collisional transition from subduction-to intraplate-type magmatism in the westernmost Mediterranean: evidence for continental-edge delamination of subcontinental lithosphere. Journal of Petrology, 46: 11551201

Ernst, R.E., Buchan, K.L., and Campbell, I.H., 2005. Frontiers in large igneous province research. Lithos, 79: 271-297.

Fedo, C.M., Young, G.M., and Nesbitt, G.M., 1997, Paleoclimatic control on the composition of the Paleoproterozoic Serpent Formation, Huronian Supergroup, Canada: A greenhouse to icehouse transition. Precambrian Research, 86: 201-223.

Fitton, J.G., James, D., Kempton, P.D., Ormerod, D.S., and Leeman, W.P., 1988. The role of lithospheric mantle in the generation of Late Cenozoic basic magmas in the Western United States. Journal of Petrology, Special Volume (1): 331349.

Floyd, P.A., and Winchester, J.A., 1978. Identification and discrimination of altered and metamorphosed volcanic rocks using immobile elements. Chemical Geology, 21: 291-306.

Gao, X., Wei, J.H., Fu, L.B., Wang, M., Zhang, L., and Yue, P., 2014. Geochemical character and tectonic significance of the Kalagang Formation volcanic rocks in Tuoli area, West Jungger. Geological Science and Technology Information, 33 (5): 16-24 (in Chinese with English abstract)

Ge, S., Zhai, M., Safonova, I., Li, D., Zhu, X., Zuo, P., and Shan, H.X., 2015. Whole-rock geochemistry and $\mathrm{Sr}-\mathrm{Nd}-\mathrm{Pb}$ isotope systematics of the Late Carboniferous volcanic rocks of the Awulale metallogenic belt in the western Tianshan Mountains (NW China): Petrogenesis and geodynamical implications. Lithos, 228-229: 62-77.

Gorton, M.P., and Schandl, E.S., 2000. From continents to island arcs: A geochemical index of tectonic setting for arc-related and within plate felsic to intermediate volcanic rocks. Canadian Mineralogist, 38: 1065-1073.

Han, B.F., Guo, Z.J., Zhang, Z.C., Zhang, L., Chen, J.F., and Song, B., 2010. Age, geochemistry, and tectonic implications of a late Paleozoic stitching pluton in the North Tian Shan suture zone, western China. Geological Society of America Bulletin, 122: 627-640

Han, B.F., Ji, J.Q., Song, B., Chen, L.H., and Zhang, L., 2006. Late Paleozoic vertical growth of continental crust around the Junggar Basin, Xinjiang, China (Part I): timing of postcollisional plutonism. Acta Petrologica Sinica, 22: 1077-1086 (in Chinese with English abstract).

Hastie, A.R., Kerr, A.C., Pearce, J.A., and Mitchell, S.F., 2007. Classification of altered volcanic island arc rocks using immobile trace elements: development of the Th-Co discrimination diagram. Journal of Petrology, 48: 2341-2357.

Hawkesworth, C.J., Turner, S.P., McDermott, F.P., and van Calsteren, D.W., 1997. U-Th isotopes in arc magmas: implications for element transfer from subducted crust. Science, 276: 561-555.

He, G.Q., Li, M.S., and Liu, D.Q., 1994. Paleozoic crust evolution and ore-forming in Xinjiang, China. Hongkong. Hongkong Education and Culture Publication House, 1-437 (in Chinese).

He, G.Q., Liu, D.Q., Li, M.S., Tang, Y.L., and Zhou, R.H., 1995. Five phases pattern and ore-forming of main orogenic belt crust evolution in Xinjiang. Xinjiang Geology, 13(2): 99-194 (in Chinese)

Hofmann, A.W., 1997. Mantle geochemistry: the message from oceanic volcanism. Nature, 385: 219-229.

Hofmann, A.W., Jochum, K.P., Seufert, M., and White, W.M., 1986. $\mathrm{Nb}$ and $\mathrm{Pb}$ in oceanic basalts: New constraints on mantle evolution. Earth and Planetary Science Letters, 79: 3345 .

Hu, X., Jansa, L., Chen, L., Griffin, W.L., O"Reilly, S.Y., and Wang, J., 2010. Provenance of Lower Cretaceous Wölong volcaniclastics in the Tibetan Tethyan Himalaya: Implications for the final breakup of Eastern Gondwana. Sedimentary Geology, 223: 193-205.

Huang, H., Zhang, Z.C., Santosh, M., Zhang, D.Y., and Wang, T., 2015. Petrogenesis of the Early Permian volcanic rocks in the Chinese South Tianshan: Implications for crustal growth in the Central Asian Orogenic Belt. Lithos, 228-229: 23-42.

Huang, B., Fu, D., Kusky, T., Ruan, K,P., Zhou, W,X., Zhang, $\mathrm{X}, \mathrm{H} ., 2$ 2018. Sedimentary provenance in response to Carboniferous arc-basin evolution of East Junggar and North Tianshan belts in the southwestern Central Asian Orogenic Belt. Tectonophysics, 722: 324-341.

Jahn, B.M., Natal'in, B.A., Windley, B.F., and Dobretsov, N., 2004. Phanerozoic continental growth in Central Asia. Journal of Asian Earth Sciences, 23: 599-603.

Jahn, B.M., Wu, F., Lo, C.H., and Tsai, C.H., 1999. Crust-mantle interaction induced by deep subduction of the continental crust: geochemical and $\mathrm{Sr}-\mathrm{Nd}$ isotopic evidence from postcollisional mafic-ultramafic intrusions of the northern dabie complex, central China. Chemical Geology, 365: 119146.

Jahn, B.M., Wu, F.Y., and Chen, B., 2000. Massive granitoid generation in Central Asian: $\mathrm{Nd}$ isotope evidence and implication for continental growth in the Phanerozoic. Episodes, 23: 82-92.

Jiang, C.Y., Cheng, S.L., Ye, S.F., Xia, M.Z., Jiang, H.B., Dai, and Y.C., 2006. Lithogeochemistry and petrogenesis of Zhongposhanbei mafic rock body, at Beishan region, Xinjiang. Acta Petrologica Sinica, 22(1): 115-126 (in Chinese with English abstract).

Jourdan, F., Bertrand, H., Sharer, U., Blichert-Toft, J., Féraud, G., and Kampunzu, A.B., 2007. Major and trace element and $\mathrm{Sr}, \mathrm{Nd}, \mathrm{Hf}$, and $\mathrm{Pb}$ isotope compositions of the Karoo large igneous province in Botswana-Zimbabwe: Lithosphere vs mantle plume contribution. Journal of Petrology, 48: 10431077.

Kamp, P.C., and Leake, B.E., 1985. Petrography and geochemistry of feldspathic and mafic sediments of the northeastern Pacific margin. Transactions of the Royal Society of Edinburgh Earth Sciences, 76(4): 411-449.

Keppler, H., 1996. Constraints from partitioning experiments on the composition of subduction-zone fluids. Nature, 380: 237240.

Khain, E.V., Bibikova, E.V., Kroner, A., Zhuravlev, D.Z., Skelyarov, E.V., Fedotova, A.A., and KravchenkoBerezhnoy, I.R., 2002. The most ancient ophiolite of the Central Asian fold belt: $\mathrm{U}-\mathrm{Pb}$ and $\mathrm{Pb}-\mathrm{Pb}$ zircon ages for the Dunzhugur Complex, Eastern Sayan, Siberria, and geodynamic implications. Earth and Planet Science Letters, 19: 311-325.

Kieffer, B., Arndt, N., Lapierre, H., Bastien, F., Bosch, D., Pecher, A., Yirgu, G., Ayalew, D., Weise, D., Jerram, D.A., Keller, F., and Meugniot, C., 2004. Flood and shield basalts from Ethiopia: Magmas from the African superswell. Journal of Petrology, 45: 793-834.

Kovalenko, V.I., Yarmolyuk, V.V., Kovach, V.P., Kotov, A.B., Kozakov, I.K., Salnikova, E.B., and Larin, A.M., 2004. Isotopic provinces, mechanism of generation and sources of the continental crust in the Central Asian mobile belt: geological and isotopic evidence. Journal of Asian Earth Sciences, 23: 605-627.

Kröner, A., Alexeiev, D.V., Rojas-Agramonte, Y., Hegner, E., Wong, J., Xia, X., Belousova, E., Mikolaichuk, A.V., Seltmann, R., Liu, D., Kiselev, V.V., 2013. Mesoproterozoic (Grenvilleage) terranes in the Kyrgyz North Tianshan: Zircon ages and Nd-Hf isotopic constraints on the origin and 
evolution of basement blocks in the southern Central Asian Orogen. Gondwana Research, 23: 272-295.

Kröner, A., Kovach, V., Belousova, E., Hegner, E., Armstrong, R., Dolgopolova, A., Seltmann, R., Alexeiev, D.V., Hoffmann, J.E., Wong, J., Sun, M., Cai, K., Wang, T., Tong, Y., Wilde, S.A., Degtyarev, K.E., Rytsk, E., 2014. Reassessment of continental growth during the accretionary history of the Central Asian Orogenic Belt. Gondwana Research, 25: 103-125.

Kröner, A., Kovach, V., Belousova, E., Hegner, E., Armstrong, R., Dolgopolova, A., Seltmann, R., Alexeiev, D.V., Hoffmann, J.E., Wong, J., Sun, M., Cai, K., Wang, T., Tong, Y., Wilde, S.A., Degtyarev, K.E., Rytsk, E., 2014. Reassessment of continental growth during the accretionary history of the Central Asian Orogenic Belt. Gondwana Research, 25: 103-125.

Kuibida, M.L., Dyachkov, B.A., Vladimirov, A.G., Kruk, N.N., Khromykh, S.V., Kotler, P.D., Rudnev, S.N., Kruk, E.A., Kuibida, Y.V., and Oitseva, T., 2018. Contrasting granitic magmatism of the Kalba fold belt (East Kazakhstan): Evidence for Late Paleozoic post-orogenic events. Journal of Asian Earth Sciences, https://doi.org/10.1016/ j.jseaes.2018.08.027.

Kwon, S.T., Tilton, G.R., Coleman, R.G., and Feng, Y., 1989. Isotopic studies bearing on the tectonics of the west Junggar region, Xinjiang, China. Tectonics, 8: 719-727.

Le Maitre, R.W., et al., 1989. A Classification of Igneous Rocks and Glossary of Terms. Blackwell, Oxford, 1-193.

Li, B., Zhuang, X., Querol, X., Moreno, N., Córdoba, P., Li, J., Zhou, J., Ma, X., Liu, S., and Shangguan, Y., which year. The mode of occurrence and origin of minerals in the Early Permian high rank coals of the Jimunai depression, Xinjiang Uygur Autonomous Region, NW China. International Journal of Coal Geology, 205: 58-47.

Li, D., 2016. Carboniferous tectonic framework and sedimentary filling evolution in the Junggar Basin and adjacent area, NW China. PhD thesis, China University of Geosciences (Beijing), $1-201$.

Li, D., He, D.F., Santosh, M., and Tang, J.Y., 2014. Petrogenesis of Late Paleozoic volcanics from the Zhaheba depression, East Junggar: Insights into collisional event in an accretionary orogen of Central Asia. Lithos, 184-187: 167-193.

Li, D., He, D.F., Ma, D.L., Tang, Y., Kong, Y.H., and Tang, J.Y., 2015. Carboniferous-Permian tectonic framework and its later modifications to the area from eastern Kazakhstan to southern Altai: Insights from the Zaysan-Jimunai Basin evolution. Journal of Asian Earth Sciences, 113: 16-35.

Liegeois, L.P., 1998. Preface - some words on the postcollisional magmatism. Lithos, 45: 15-17.

Liu, W.L., Huang, Q.T., Gu, M., Zhong, Y., Zhou, R., Gu, X.D., Zhou, R.J., Gu, X.D., Zheng, H., Liu, J. N., Lu, X.X., and Xia, B., 2018. Origin and tectonic implications of the Shiquanhe high-Mg andesite, western Bangong suture, Tibet. Gondwana Research, 60: 1-14.

Liu, Y.S., Hu, Z.C., Gao, S., Güntherc, D., Xu, J., Gao, C.G., and Chen, H.H., 2008. In situ analysis of major and trace elements of anhydrous minerals by LA-ICP-MS without applying an internal standard. Chemical Geology, 257: 34-43.

Long, L.L., Gao, J., Wang, J.B., Qian, B., Xiong, X.M., Wang, Y.W., Wang, L.J., and Gao, L.M., 2008. Geochemistry and SHIRMP zircon U-Pb age of post-collisional granites in the Southwest Tianshan orogenic belt of China: examples from the Heiyingshan and Laohutai plutons. Acta Geologica Sinica (English Edition), 82(2): 415-424.

Ma, X.H., Cao, R., Zhou, Z.H., and Zhu, W.P., 2015. Early Cretaceous high-Mg diorites in the Yanji area, northeastern China: petrogenesis and tectonic implications. Journal of Asian Earth Sciences, 97: 393-405.

MacDonald, G. A., and Katsura, T., 1964. Chemical composition of Hawaiian lavas. Journal of Petrology, 5(1): 82-133.

McLennan, S.M, 1993. Weathering and global denudation. Journal of Geology, 101: 295-303.

McLennan, S.M, Hemming, S., McDaniel, D.K., and Hanson, G.N., 1993. Geochemical approaches to sedimentation, provenance, and tectonics. Geological Society of America
Bulletin, 284: 21-40 (Special Paper)

McLennan, S.M., Hemming, S.R., Taylor, S.R., and Eriksson, K.A., 1995. Early Proterozoic crustal evolution: Geochemical and $\mathrm{Nd}-\mathrm{Pb}$ isotopic evidence from metasedimentary rocks, southwestern North America. Geochimica et Cosmochimica Acta, 59(6): 1153-1177.

Meinhold, G., Kostopoulos, D., and Reischmann, T., 2007. Geochemical constraints on the provenance and depositional setting of sedimentary rocks from the islands of Chios, Inousses and Psara, Aegean Sea, Greece: implications for the evolution of Palaeotethys. Geological Society of London, Special Publication, 164: 1145-1163.

Nesbitt, H.W, and Young, G.M., 1982. Early Proterozoic climates and plate motions inferred from major element chemistry of lutites. Nature, 299: 715-717.

Nesbitt, H.W, Young, G.M., 1984. Prediction of some weathering trends of plutonic and volcanic rocks based on thermodynamic and kinetic considerations. Geochimica Et Cosmochimica Acta, 48(7): 1523-1534.

Nesbitt, H.W, and Young, G.M., 1989. Formation and diagenesis of weathering profiles. Journal of Geology, 97(2): 129-147.

Neumann, E.R., Svensen, H., Galerne, C.Y., and Planke, S., 2011. Multistage evolution of dolerites in the Karoo large igneous province, Central South Africa. Journal of Petrology, 52: 959-984.

Peacock, S.M., 1990. Numerical simulation of metamorphic pressure-temperaturetime paths and fluid production in subducting slabs. Tectonics, 9: 1197-1211.

Pearce, J.A., 1982. Trace element characteristics of lavas from destructive plate boundaries. In: Thorps, R.S. (ed.), Andesites. John Wiley and Sons, New York, 525-548.

Pearce, J.A., and Norry, M.J., 1979. Petrogenetic implications of $\mathrm{Ti}, \mathrm{Zr}, \mathrm{Y}$ and $\mathrm{Nb}$ variations in volcanic rocks. Contributions to Mineralogy and Petrology, 69: 33-47.

Reza, D., and Alijan, A., 2016. Geochemical provenance of soils in Kerman urban areas, Iran: Implications for the influx of aeolian dust. Aeolian Research, 21: 109-123.

Rieu, R., Allen, P.A., Plötze, M., and Pettke, T, 2007, Climatic cycles during a Neoproterozoic "snowball" glacial epoch, Geology, 35: 299-302.

Roser, B.P., Coombs, D.S., Korsch, R.J., Campbell, J.D., 2002. Whole-rock geochemical variation and evolution of the arcderived Murihiku Terrane, New Zealand. Geological Magazine, 139: 665-685.

Safonova, I.Y., 2017. Juvenile versus recycled crust in the Central Asian Orogenic Belt: implications from ocean plate stratigraphy, blueschist belts and intra-oceanic arcs. Gondwana Research, 47: 6-27.

Safonova, I.Y., Utsunomiya, A., Kojima, S., Nakae, S., Tomurtogoo, O., Filippov, A.N., and Koizumi, K., 2009. Pacific superplume-related oceanic basalts hosted by accretionary complexes of Central Asia, Russian Far East and Japan. Gondwana Research, 16: 587-608.

Safonova, I.Y., Sennikov, N.V., Komiya, T., Bychkova, Y.V., and Kurganskaya, E.V., 2011. Geochemical diversity in oceanic basalts hosted by the Zasur'ya accretionary complex, NW Russian Altai, Central Asia: Implications from trace elements and Nd isotopes. Journal of Asian Earth Sciences, 42: 191-207.

Safonova, I.Y., Simonov, V.A., Kurganskaya, E.V., Obut, O.T., Romer, R.L., and Seltmann, R., 2012. Late Paleozoic oceanic basalts hosted by the Char suture-shear zone, East Kazakhstan: geological position, geochemistry, petrogenesis and tectonic setting. Journal of Asian Earth Sciences, 49: 2039.

Samir, M.Z., 2015. Geochemistry of sandstones from the Pliocene Gabir Formation, north Marsa Alam, Red Sea, Egypt: Implication for provenance, weathering and tectonic setting. Journal of African Earth Sciences, 102: 1-17.

Schandl, E.S., and Gorton, M.P., 2002. Application of high field strength elements to discriminate tectonic settings in VMS environments. Economic Geology, 97(3): 629-642.

Sengör, A.M.C., Natal'in, B.A., and Burtman, U.S., 1993. Evolution of the Altaid tectonic collage and Paleozoic crustal growth in Eurasia. Nature, 364: 209-304. 
Sennikov, N.V., Iwata, K., Ermikov, V.D., Obut, O.T., and Khlebnikova, T.V., 2003. Oceanic sedimentation settings and fauna associations in the Paleozoic on the southern framing of the West Siberian Plate. Russian Geology and Geophysics, 44: 156-171.

Sevcan, K., and Özge, T., 2017. Geochemical and Sr-Nd isotopic characteristics of Upper Cretaceous (calc-alkaline) and Miocene (alkaline) volcanic rocks: Elazıg, Eastern Taurides, Turkey. Journal of African Earth Sciences, 134: 332-344.

Shu, X., Yang, S.Y., Jiang, S.Y., and Ye, M., 2017. Petrogenesis and geodynamic setting of Early Cretaceous felsic rocks in the Gan-Hang Belt, Southeast China: Constraints from geochronology and geochemistry of the tuffs and trachyandesitic rocks in Shengyuan volcanic Basin. Lithos, 284-285: 691-708.

Stephanie, R., Carita, A., Rocio, N.I., Uwe, J., and Peter S., 2012. Provenance and depositional conditions of CretaceousPaleogene boundary sandstones from northeastern Mexico. Sedimentary Geology, 282: 321-335.

Su, Y.P., Tang, H.F., Hou, G.S., and Liu, C.Q., 2006. Geochemistry of aluminous A-type granites along Darabut tectonic belt in West Junggar, Xinjiang. Geochemica, 35: 1-5 (in Chinese with English abstract).

Su, Y.P., Zheng, J.P., Griffin, W.L., Zhao, J.H., Tang, H.Y., Ma, Q., and Lin, X.Y., 2012. Geochemistry and geochronology of Carboniferous volcanic rocks in the eastern Junggar terrane, NW China: implication for a tectonic transition. Gondwana Research, 22: 1009-1029.

Sun, W.D., Hu, Y.H., Kamenetsky, V.S., Eggins, S.M., Chen, M., and Arculus, R.J., 2008. Constancy of Nb/U in the mantle revisited. Geochimica et Cosmochimica Acta, 72: 3542-3549.

Sun, S.S., and McDonough, W.F. 1989. Chemical and isotopic systematics of oceanic basalts: implications for mantle composition and processes. Geological Society, London, Special Publications, 42(1): 313-345.

Tan, L.G, Zhou, T.F., Yuan, F., Fan. Y., and Yue, S.C., 2006. Mechanism of formation of Permian volcanic rocks in Saur region, Xinjiang, China: Constraints from rare earth elements. Journal of Rare Earths, 24: 626-632.

Tang, D.M., Qin, K.Z., Xue, S.C., Mao, Y.J., Evans, N.J., Niu, Y.J., and Chen, J.L., 2017. Genesis of the Permian Kemozibayi sulfide-bearing mafic-ultramafic intrusion in Altay, NW China: Evidence from zircon geochronology, Hf and O isotopes and mineral chemistry. Lithos, 292-293: 4968.

Tang, D.M., Qin, K.Z., Sun, H., Su, B.X., and Xiao, Q.H., 2012. The role of crustal contamination in the formation of $\mathrm{Ni}-\mathrm{Cu}$ sulfide deposits in Eastern Tianshan, Xinjiang, Northwest China: evidence from trace element geochemistry, Re-Os, Sr$\mathrm{Nd}$, zircon Hf-O, and sulfur isotopes. Journal of Asian Earth Sciences, 49: 145-160.

Tang, G.J., Wang, Q., Wyman, D.A., Sun, M., Zhao, Z.H., and Jiang, Z.Q., 2013. Petrogenesis of gold-mineralized magmatic rocks of the Taerbieke area, northwestern Tianshan (western China): constraints from geochronology, geochemistry and Sr$\mathrm{Nd}-\mathrm{Pb}-\mathrm{Hf}$ isotopic compositions. Journal of Asian Earth Sciences, 74(S1): 113-128.

Tatsumi, Y., and Eggins, S.M., 1995. Subduction Zone Magmatism. Blackwell Science, Cambridge, 1-211.

Taylor, S.R., and McLennan, S.M., 1985. The Continental Crust: Its Composition and Evolution Blackwell, Oxford, 1-311

Treuil, M., and Varet, J., 1973. Criteres volcanologiques, petrologiques et geochimiques de la genese et de la differenciation des magmas basaltiques; exemple de l'Afar. Bulletin de la Société Géologique de France, S7-XV: 506540.

Uwe, J., and Ulrich, R., 2002. Continental Triassic in Argentina: Response to tectonic activity. Journal of South American Earth Sciences, 15: 461-479.

Vladimirov, A.G., Kruk, N.N., Khromykh, S.V., Polyansky, O.P., Chervov, V.V., Vladimirov, V.G., Travin, A.V., Babin, G.A., Kuibida, M.L., and Khomyakov, V.D., 2008. Permian magmatism and lithospheric deformation in the Altai caused by crustal and mantle thermal processes. Russian Geology and Geophysics, 49: 468-479.
Wang, B., Cluezel, D., Shu, L.S., Faure, M., Charver, J., Chen, Y., Meffre, S., and Jong, K.D., 2009. Evolution of calcalkaline to alkaline magmatism through Carboniferous convergence to Permian transcurrent tectonics, western Chinese Tianshan. International journal of Earth Science, 98: $1275-1298$

Wang, J.B., and Xu, X., 2006. Post-collisional tectonic evolution and metallogenesis in northern Xinjiang, China. Acta Geologica Sinica, 80(1): 23-31 (in Chinese with English abstract).

Wang, Q., Li, Z.X., Chung, S.L., Wyman, D.A., Sun, Y.L., and Zhao, Z.H., 2011. Late Triassic high Mg andesite/dacite suites from northern Hohxil, North Tibet: geochronology, geochemical characteristics, petrogenetic processes and tectonic implications. Lithos, 126(1): 54-67.

Wang, Q., Xu, J.F., Jian, P., Bao, Z., Zhao, Z.W., Zhao, Z.H., Li, C.F., Xiong, X.L., and Ma, J.L., 2006. Petrogenesis of adakitic porphyries in an extensional tectonic setting, Dexing, South China: Implications for the genesis of porphyry copper mineralization. Journal of Petrology, 47(1): 119-144.

Wang, T., Jahn, B.M., Kovach, V.P., Tong, Y., Hong, D.W., and Han, B.F., 2009. Nd-Sr isotopic mapping of the Chinese Altai and implications for continental growth in the Central Asian Orogenic Belt. Lithos, 110: 359-372.

Whalen, J.B., McNicoll, V.J., van Staal, C.R., Lissenberg, C.J., Longstaffe, F.J., Jenner, G.A., and van Breeman, O., 2006. Spatial, temporal and geochemical characteristics of Silurian collision-zone magmatism, Newfoundland Appalachians: An example of a rapidly evolving magmatic system related to slab break-off. Lithos, 89: 377-404.

Wilhem, C., Windley, B.F., and Stampfli, G.M., 2012. The Altaids of Central Asia: A tectonic and evolutionary innovative review. Earth Science Reviews, 113: 303-341.

Windley, B.F., Alexeiev, D.V., Xiao, W., Kröner, A., and Badarch, G., 2007. Tectonic models for accretion of the Central Asian Orogenic Belt. Journal of Geological Society, London, 164: 31-47.

Windley, B.F., Kroner, A., Guo, J.H., Qu, G.S., Li, Y.Y., and Zhang, C., 2002. Neoproterozoic to Paleozoic geology of the Altai Orogen, NW China: new zircon age data and tectonic evolution. Journal of Geology, 110(6): 719-737.

Xia, L.Q., 2014. The geochemical criteria to distinguish continental basalts from arc related ones. Earth Science Reviews, 139: 195-212.

Xia, L.Q., and Li, X.M., 2019. Basalt geochemistry as a diagnostic indicator of tectonic setting. Gondwana Research, 65: 43-67.

Xia, L.Q., Xia, Z.C., Xu, X.Y., Li, X.M., and Ma, Z.P., 2008. Relative contributions of crust and mantle to the generation of the Tianshan Carboniferous rift-related basic lavas, northwestern China. Journal of Asian Earth Sciences, 31: 357 $-378$

Xia, L.Q., Li, X.M., Yu, J.Y., and Wang, G.Q., 2016. Mid-Late Neoproterozoic to Early Paleozoic volcanism and tectonic evolution of the Qilianshan, NW China. Geological Research Journal, 9-12: 1-41.

Xiao, W.J., Han, C.M., Liu, W., Wan, B., Zhang, J.E., Ao, S.J., Zhang, Z.Y., Song, D.F., Tian, Z.H., and Luo, J., 2014. How many sutures in the southern Central Asian Orogenic Belt: Insights from East Xinjiang-West Gansu (NW China)? Geoscience Frontiers, 5: 525-536.

Xiao, W.J., Han, C.M., Yuan, C., Sun, M., Lin, S.F., Chen, H.L., Li, Z.L., Li, J.L., and Sun, S., 2008. Middle Cambrian to Permian subduction-related accretionary orogenesis of North Xinjiang, NW China: implications for the tectonic evolution of Central Asia. Journal of Asian Earth Sciences, 32: 102117.

Xiao, W.J., Huang, B.C., Han, CM., Sun, S., and Li, J. L., 2010. A review of the western part of the Altaids: a key to understanding the architecture of accretionary orogens. Gondwana Research, 18: 253-273.

Xiao, W.J., Windley, B.F., Allen, M., and Han, C.M., 2013. Paleozoic multiple accretionary and collisional tectonics of the Chinese Tianshan orogenic collage. Gondwana Research, 23: $1316-1341$. 
Xiao, W.J., Windley, B.F., Yuan, C., Sun, M., Han, C.M., Lin, S.F., Chen, H.L., Yan, Q.R., Liu, D.Y., Qin, K.Z., Li, J.L., and Sun, S., 2009. Paleozoic multiple subduction-accretion processes of the southern Altaids. American Journal of Science, 309: 221-270.

Xiang, Z., Yan, Q., White, J.D.L., Song, B., and Wang, Z., 2015. Geochemical constraints on the provenance and depositional setting of Neoproterozoic volcaniclastic rocks on the northern margin of the Yangtze Block, China: Implications for the tectonic evolution of the northern margin of the Yangtze Block. Precambrian Research, 264: 140-155.

Xu, X.W., Jiang, N., Li, X.H., Qu, X., Yang, Y.H., Mao, Q., Wu, Q., Zhang, Y., and Dong, L.H., 2013. Tectonic evolution of the East Junggar terrane: evidence from the Taheir tectonic window, Xinjiang, China. Gondwana Research, 24: 578-600.

Yan, D.T., Chen, D.Z., Wang, Q.C., and Wang, J.G., 2010. Large-scale climatic fluctuations in the latest Ordovician on the Yangtze block, south China. Geology, 38: 599-602.

Yan, Z., Wang, Z.Q., Yan, Q.R., Wang, T., and Guo, X.Q., 2012. Geochemical constraints on the provenance and depositional setting of the Devonian Liuling Group, East Qinling Mountains, central China: implications for the tectonic evolution of the Qinling Orogenic Belt. Journal of Sedimentary Research, 82: 9-20.

Yang, G., Li, Y., Safonova, I., Yi, S., Tong, L., and Seltmann, R., 2014. Early Carboniferous volcanic rocks of West Junggar in the western Central Asian Orogenic Belt: implications for a supra-subduction system. International Geology Review, 56: 823-844.

Yang, X.F., He, D.F., Wang, Q.C., Tang, Y., Tao, H.F., and Li, D., 2012. Provenance and tectonic setting of the Carboniferous sedimentary rocks of the East Junggar Basin, China: Evidence from geochemistry and U-Pb zircon geochronology. Gondwana Research, 22: 567-584.

You, G.F., Castillo, P.R., Gieskes, J.M., Chan, L.H., and Spivack, A.J., 1996. Trace element behaviour in hydrothermal experiments: implications for fluid processes at shallow depths in subduction zones. Earth Planet Science Letters, 140: 41-52.

Zhang, Y.Y., Guo, Z.J., Pe-Piper, G., and Piper, D.J.W., 2015. Geochemistry and petrogenesis of Early Carboniferous volcanic rocks in East Junggar, North Xinjiang: Implications for post-collisional magmatism and geodynamic process. Gondwana Research, 28: 1466-1481.

Zheng, J.P., Sun, M., Zhao, G.C., Robinson, P.T., and Wang, F.Z., 2007. Elemental and $\mathrm{Sr}-\mathrm{Nd}-\mathrm{Pb}$ isotopic geochemistry of Late Paleozoic volcanic rocks beneath the Junggar basin, NW
China: Implications for the formation and evolution of the basin basement. Journal of Asian Earth Sciences 29: 778-794.

Zhou, J.X. 1999. Geochemistry and Petrogenesis of Igneous Rocks Containing Amphibole and Mica: A Case Study of Plate Collision Involving Scotland and Himalayas. New York and Beijing: Science Press, 41-72.

Zhou, T.F., Yuan, F., Tan, L.G., Fan, Y., and Yue, S.C., 2006. Geodynamic significance of the A-type granites in the Saur region in west Junggar, Xinjiang: Rock geochemistry and SHRIMP zircon age evidence. Science in China: Series D Earth Sciences, 49(2): 113-123.

Zhou, T., Yuan, F., Fan, Y., Zhang, D., Cooke, D., and Zhao, G., 2008. Granites in the Saur region of the west Junggar, Xinjiang Province, China: Geochronological and geochemical characteristics and their geodynamic significance. Lithos, 106: 191-206.

Zhuang, L., Chen, B., Wei, C., Wang, C., and Wei, H., 2015. Provenance and tectonic setting of the Paleoproterozoic metasedimentary rocks from the Liaohe Group, Jiao-Liao-Ji Belt, North China Craton: Insights from detrital zircon U-Pb geochronology, whole rock Sm-Nd isotopes, and geochemistry. Journal of Asian Earth Sciences, 111: 711-732.

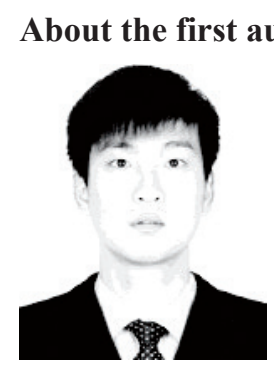

SHANGGUAN Yunfei, male, born in 1991 in Jincheng City, Shanxi Province; Ph.D. doctor; studying at China University of Geosciences (Wuhan); major in mineral resources prospecting and exploration. Email: SGyunfei@cug.edu.cn; phone: 13209876065.

\section{About the corresponding author}

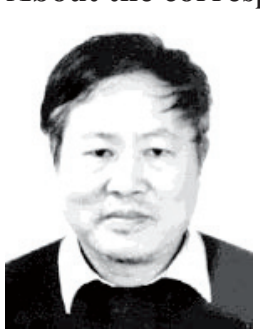

ZHUANG Xinguo, male, born in 1957 in Changsha City, Hunan Province; Ph.D. doctor; graduated from China University of Geosciences (Wuhan); professor of the School of the Earth Resource, China University of Geosciences (Wuhan); major research in coal geology and coal geochemistry; Email: xgzhuang@cug. edu.cn; phone: 13507157383 . 